\title{
The Geometric Enigma of Small Baths at Hadrian's Villa: Mixtilinear Plan Design and Complex Roofing Conception
}

\author{
Luca Cipriani $^{1} \cdot$ Filippo Fantini $^{1}(\mathbb{D})$ \\ Silvia Bertacchi ${ }^{2}$
}

Published online: 15 May 2017

(C) Kim Williams Books, Turin 2017

\begin{abstract}
Starting in the late Domitian age, through Nero's Empire and ending in Hadrian's principate, an increasing technological shift relating to both opus caementicium and centring work made it possible to build cupolas with unprecedented technical solutions in terms of both dimension and shape. Hadrian's strain was applied to the development of innovative domes, as shown in various pavilions in his Tiburtine Villa and perfectly expressed by the well-known episode reported by Cassius Dio concerning the criticism expressed by Apollodorus of Damascus on the Emperor's ribbed vault design. Many researchers agree on the importance of the octagonal hall of the Villa's Small Baths in terms of its unusual shape and daring structure and on the significance of the access vestibule of the Piazza d'Oro. The geometry and construction knowledge suggested by their shapes make them perfect examples of the importance of mathematicians' influence on architects during the design process.
\end{abstract}

Keywords Design analysis · Design theory · Historical era: II century a.D. · Hadrian's Villa · Small Baths · Descriptive geometry · Grids · Polygons

Luca Cipriani

luca.cipriani@unibo.it

Filippo Fantini

filippo.fantini2@unibo.it

Silvia Bertacchi

silvia.bertacchi@unibo.it

1 Department of Architecture, Alma Mater Studiorum - Università di Bologna, Viale Risorgimento 2, Bologna, Italy

2 Interdepartmental Centre for Industrial ICT Research, Alma Mater Studiorum - Università di Bologna, Viale Risorgimento 2, Bologna, Italy 


\section{Introduction}

During the last 10 years, several surveying campaigns on the archaeological site of Hadrian's Villa have been conducted by universities and research organisations using cutting-edge technologies, including laser scanners (phase-shift, time-of-flight and triangulation-based); image-based modelling (IBM) pipelines based on Structure from Motion, Multi-View Stereo (SfM-MVS); ground-penetrating radar (GPR) and, last but not least, traditional archaeological and architectural analyses.

Most of the monumental pavilions of this UNESCO site have been accurately surveyed (Bertocci 2015), and starting from reliable and flexible three-dimensional reality-based models of both masonry and marble elements (belonging to entablatures and columns), new research lines have achieved consistent results in the field of the virtual anastylosis/reconstruction of mixtilinear plan buildings. ${ }^{1}$

Representative pavilions of the Villa incorporated innovative solutions based on alternating straight or curved portions of trabeation, bowed trabeation alternating bent portions and cusps. The three main examples of these architectural features are very well known because they inspired numerous formal solutions of the Baroque in Rome, Europe and beyond. ${ }^{2}$ They are the Maritime Theatre, the Piazza d'Oro (Golden Square) and the Serapeum/Canopus complex.

To go beyond the interesting-but limited-purpose of re-assembling and completing trilithon typologies (e.g., friezes, cornices, epistyles, capitals and shafts), a new line of investigation with a wider scope has been initiated: integrating the results obtained relating to mixtilinear design in plans with a deeper knowledge of vaulted and domical structures in Roman concrete (opus caementicium). This topic is of great historical and architectural interest because it connects and underlines the legacy of Hadrian's Villa with the history of Western architecture, as witnessed by several examples ranging from Byzantine (Hagia Sophia, Saints Sergius and Baccus, and San Vitale) to Baroque sacred architecture, especially the interiors (Santa Maria dei Sette Dolori, San Carlo alle Quattro Fontane, Sant'Ivo alla Sapienza by Borromini and San Lorenzo by Guarino Guarini).

Hadrian's interest in architecture gave more concrete shape to earlier, probably immature and episodic experiments with vaulted structures based on the extensive use of opus caementicium technology. ${ }^{3}$

His legacy, which is still perceivable in the later examples mentioned above, was the outcome of a systematic experimentation performed by the team of architects operating at his Villa between 117 and 134 A.D. These architects were experts in both the technical/material aspects of the construction and in geometry and

\footnotetext{
1 For a complete bibliography on the topic by means of reverse modelling applications and geometrical analysis of Maritime Theatre and Piazza d'Oro, see Adembri et al. (2012), (2014), Adembri (2013).

2 On the influence of Hadrianic cupolas on Borromini's architecture, see Portoghesi (1994: 9-20 , 64); among the architects that drew inspiration from the Villa for their conceptions, a special role is held by John Soane, who carried out a detailed survey on the plans of both the Small and Great Baths (Richardson et al. 2000: 62-66).

3 On the innovative design of vaulted structures in Roman concrete, particularly with reference to the Domus Aurea and the Domus Augustana, see Ward-Perkins (1974: 59-64).
} 
mathematics applied to buildings. The roles of theoretic disciplines have always fascinated scholars of the Hadrianic legacy, particularly Jacobson (1986), the author of an essay on Hadrianic architecture and geometry who conducted extensive geometric analyses of several mixtilinear plans, and Rakob (1967), the author of an unpublished (but well-known) doctoral dissertation on the Southern Hall of Piazza d'Oro. However, none of them had at their disposal highly detailed 3D models of the mentioned mixtilinear buildings and their domes. ${ }^{4}$ For this reason, their studies could not be consistently extended to an in-depth analysis of the elevations (particularly of Roman concrete vaults).

Inside the Emperor's architectural "playground" in Tivoli, similar to but more reasonable than what Nero did before him in the very centre of Rome, architects stressed limiting the properties of opus caementicium, which is made by mixing pozzonalic materials (volcanic rock rich in silicon) with quicklime and water. Due to the passage of time (but also to poor restorations), the innovative and astonishing shapes that broke the link with tradition in Hadrian's time are now very difficult to investigate because they appear more similar to monolithic eroded rocks than to the pure and neat geometries that characterise the stereotomic vaults and cupolas of the Middle Ages or the perfectly smoothed surfaces alternating with sharp creases of the Baroque examples from Borromini and Guarini. This last aspect made this investigation more difficult than conventional plan-design geometric analysis because the identification of primitive shapes and their combinations on damaged, asymmetric and broken vaults requires the development of specific methodologies. As a result, specific software applications belonging to the field of reverse modelling assume great importance (Adembri et al. 2015: 18).

Among the many "open issues" concerning the domical structures at Hadrian's Villa are long-standing controversies regarding whether domes made of concrete (or of a different material) were present in certain pavilions, namely, the famous one at the Piazza d'Oro southern octagonal hall (Moneti 1992; Rakob 1967), the Belvedere dell'Accademia or Accademia Esplanade (Hansen et al. 2011) and the curved porticoes of the Maritime Theatre (Adembri et al. 2010).

These, in short, are the reasons why some interesting works that were executed with a true scientific spirit of inquiry can now be carefully reinterpreted and undergo substantial revisions ${ }^{5}$ based on more accurate and extensive measurements of masonry. In this sense, digital surveying technologies and 3D models facilitate performing complete documentation (of both the intrados and extrados of vaulted spaces), which would be very difficult using traditional methods. The correct

\footnotetext{
${ }^{4}$ For notable exceptions, see Verdiani et al. (2010: 259-269) and Pucci and Blanco (2011: 502-512). In the first paper, the authors report a very accurate and complete survey of Small Baths; in the second, they direct their efforts towards the three main thermal complexes of Hadrian's Villa (another smaller bath is inside Maritime Theatre). The surveys are complete, but in some specific cases, a lack of accuracy is evident, particularly in the representation of the extrados of the octagonal hall at Small Baths (Verdiani et al. 2010: 263). Indeed, the relation between the intrados and extrados of the dome cannot be approximated as a simple "offset" of the interiors; moreover, in the paragraph "Approaches to the monument reconstruction," the authors do not clarify the geometric process they used to reach the final shape.

5 For instance, Jacobson's work (1986) should be reconsidered because he based his geometrical analysis on out-dated surveys.
} 
acquisition of information on the construction phases and actual execution of the domes $^{6}$ can enable a deeper understanding of the geometrical genesis behind the structures and increased clarity regarding the application of recursive geometric constructions and mathematical formulas. In particular, clearly understanding geometric patterns (ichnographia, orthographia, and scaenographia) can enable cross-readings among centric plan pavilions: Did they apply the same or similar geometric patterns for the layouts of different buildings? Can a common construction technology be detected in various buildings in the Villa? Is it possible to imagine that, within a common master plan, different schools of thought peculiar to each working group could coexist while operating with creative independence?

In this sense, the theme of octagonal rooms seems to be one of the Villa's main features. In particular, the octagonal hall of Small Baths can be considered a prototype for further developments of Western architecture and the octagonal vestibule of the Piazza D'Oro.

\section{Central Plans: Aims and Locations Inside the Villa}

The elaboration of new shapes and the combination of previous roofing typologies with the new Hadrianic aesthetic coincided with the presence of a multidisciplinary team of experts operating on the Emperor's court, including various specialists, including sculptors, architects, musicians, mathematicians and geometers. All of these individuals came from different regions of the Empire and were assigned to the development of complex solutions to construction and design problems.

As with many pavilions of Hadrian's dwelling, the eclecticism of the formal solutions devised by Hadrian does not allow direct comparisons with the most common building types of Roman settlements; rather, there was a desire to expand beyond previous architectural and urban models that developed during the principate of Nero and Domitian and, in turn, was inspired by Eastern ephemeral architectures and canopies, mainly Persian and Alexandrian (Calandra 2013). In this sense, the recent study published by Cinque (2013: 96-98) provided the terms for thorough comparison with these inspirations. One interpretation underlines the Villa's nature as a sort of hybrid between basileion and basileia: The first term indicates the Hellenistic palace (freely articulated pavilions and buildings in a natural environment), whereas the second relates to the entire district, including the identifiable royal palace, in which the composition is more compact because the buildings are connected by porticoes and gardens, as in the Roman palatium. Therefore, the villa/city is an articulated ensemble formed by several nuclei, of which the so-called Palazzo houses the main residential areas. In that central block, a sequence of pavilions, seemingly independent with respect to one another, are roughly grouped. These pavilions extend along the western and eastern sides of a fringe of the Colli di Santo Stefano, slightly diverging from North to South (Fig. 1).

\footnotetext{
${ }^{6}$ Some previous studies on Hadrianic vaults and cupolas, such as that by Cairoli (1975), are still notable in terms of the interpretation of technological aspects.
} 


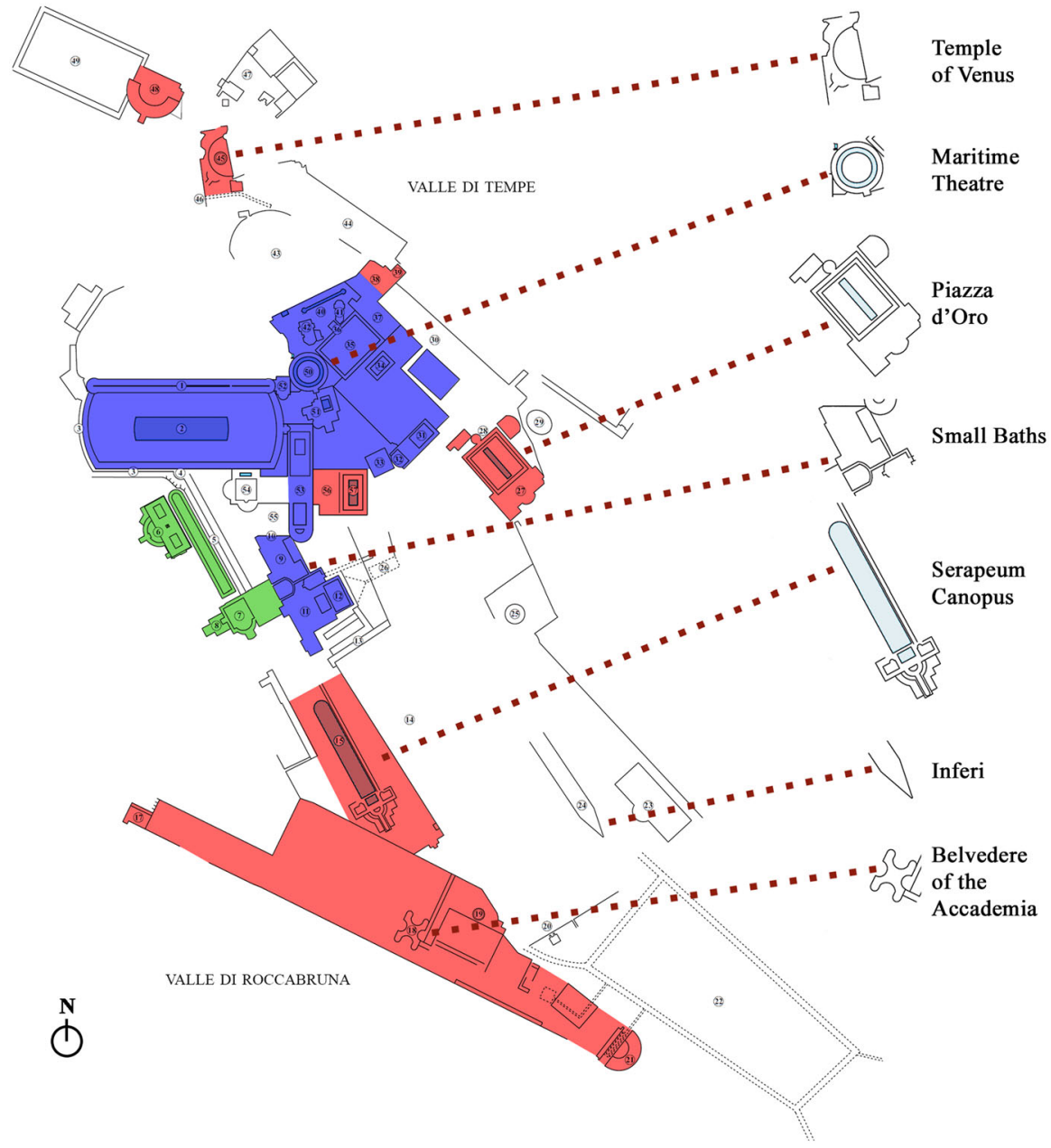

Fig. 1 Schematic plan of Hadrian's Villa with the main hypothetical construction phases; evidently, the buildings are characterised by a mixtilinear plan design. The first construction phase (118 A.D./121 A.D.) is shown in blue Maritime Theatre, Hospitalia (Hall of the Cubicules), Poecile (East-West Terrace), Cento Camerelle (Hundred Chambers), Eliocaminus Baths, Imperial Palace, Small Baths and Great Baths, the two Libraries (Latin and Greek) and the Stadium (Garden Stadium). The second phase (125 A. D./128 A.D.) is shown in red Piazza D'Oro, Temple of Venus with Nymphaeum, Stadium (completion), Canopus-Serapeum, Winter Palace, Tempe's Pavilion, Doric Pillars, Roccabruna, Accademia, Odeon, Greek Theatre and the Palestra. The third phase (133/134 A.D.) is presented in green Various works for completion and the Egyptian-like area aligned with the Vestibule (the so-called Antinoeion)

Many authors in the fields of both architecture and archaeology assume that most of the Villa was entirely planned at the beginning of Hadrian's principate, with minor work-in-progress modifications. ${ }^{7}$ Several and, in many cases, conflicting

\footnotetext{
7 The body of literature on this topic is vast; see, for instance, MacDonald and Pinto (1997) and Salza Prina Ricotti (2001).
} 
interpretation schemes are provided by scholars. ${ }^{8}$ Among them, Caliari (2012) emphasises the role of all the main centric-plan halls (particularly the vaulted ones) as knots in a network responsible for the Villa's general arrangement; this "topographic grid" of domed buildings seems to be a clear reflection of the Emperor's personal interest in cupolas. 9 Astonishing vaulted pavilions with recreational or ceremonial functions were designed and located with different scopes; the two main scopes were as follows: semi-domes at the end of long promenades (for instance, the so-called Serapeum, Summer Triclinium, and Inferi) and remarkable discoveries of huge hidden domes after a sequence of interiors and courtyards (the eastern triclinium, vestibule and southern hall of the Piazza d'Oro and the reverse-curve pavilion of Accademia and Small Baths) (Figs. 2, 3, 4).

In general, even if not all the scholars converge on a common position, ${ }^{10}$ we can agree that the general development of the Villa started from a Republican nucleus located northeast of the general boundaries of the mansion and then developed along the two expansion lines flanking the Colli di Santo Stefano. After a first intense building phase (118 A.D./121 A.D.) aimed at supplying the villa with a Palace (used for official and political functions), Hadrian's personal domus (the Maritime Theatre), a vast portico (the Poecile) and a thermal bath (Heliocaminus Baths), a second and more intellectual building programme began (125 A.D./128 A.D.). Subsequently, all of the functions and typologies included in the first phase were replicated outwards along the two expansion lines. This tendency seems to underline the Emperor's intention of constant renewal, enrichment and enlargement of triclinia, thermal baths, and nymphaea. The team of architects operating in the Villa had to conduct an experimental phase to test Hadrian's design hints and wishes. ${ }^{11}$ The third phase of the Villa (133/134 A.D.) is more difficult to identify because it probably consisted of uneven completions of buildings started in previous phases (the 120 ha of the mansion were built in less than 20 years) with the only exception being an Egyptian-style building known as the Antinoeion to the west of the access road leading to the access Vestibule (Mari and Sgalambro 2007).

\footnotetext{
${ }^{8}$ On the topic of the overall conception of Hadrian's Villa by means of geometrical analysis, see Di Tondo (2007), Giuffrida (2007), Caliari (2012), Cinque and Lazzeri (2010) and Ytterberg (2013).

${ }^{9}$ Hadrian's personal interest in ribbed vaults is widely known since the anecdote quoted by Cassius Dio about his quarrel with Apollodorus of Damascus is centred on some drawings (or models) of peculiarly shaped domes: "Be off, and draw your gourds. You don't understand any of these matters" (Dio, 3rd AD/ 1925: 69, 4). The Syrian architect considered Hadrian's designing proposals no more than amateurish, odd "experiments", but on his accession, he could finally put into practice his new aesthetic in the frame of the Tiburtine dwelling. In any case, the widespread opinion that Hadrian put to death Apollodorus once he became Emperor is denied by various evidence. Indeed, the author of Historia Augusta (...) wrote about the Emperor's collaboration with two architects, Decrianus and Apollodorus, once he ordered the movement of the colossal statue of Nero (then consecrated to the Sun) while keeping it in an upright position. He also planned, with the assistance of Apollodorus, to make a similar statue for the Moon.

${ }^{10}$ These three chronological phases are defined according to Calandra (2013), but this topic remains debated among scholars. For different points of view, see Gizzi (2002), Hoffmann (2009), Di Tondo (2007), and Caliari (2012).

11 Salza Prina Ricotti (2001) identified an area used like a designing workshop within the Great Baths complex. There, a marble model of a building for spectacle was discovered, which highlights, in combination with other findings, the presence of constant design activity in the Villa (Bianchini and Fantini 2015: 36-39).
} 

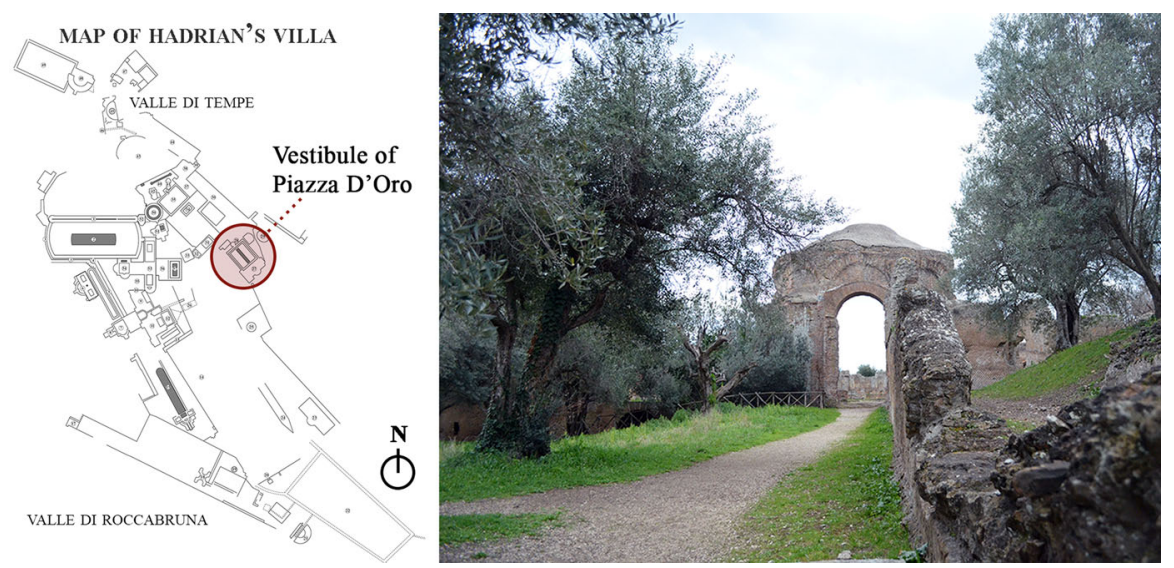

Fig. 2 Example of a cupola that could be "discovered" after progressing through a sequence of courtyards and narrow passages (Vestibule of the Piazza d'Oro)
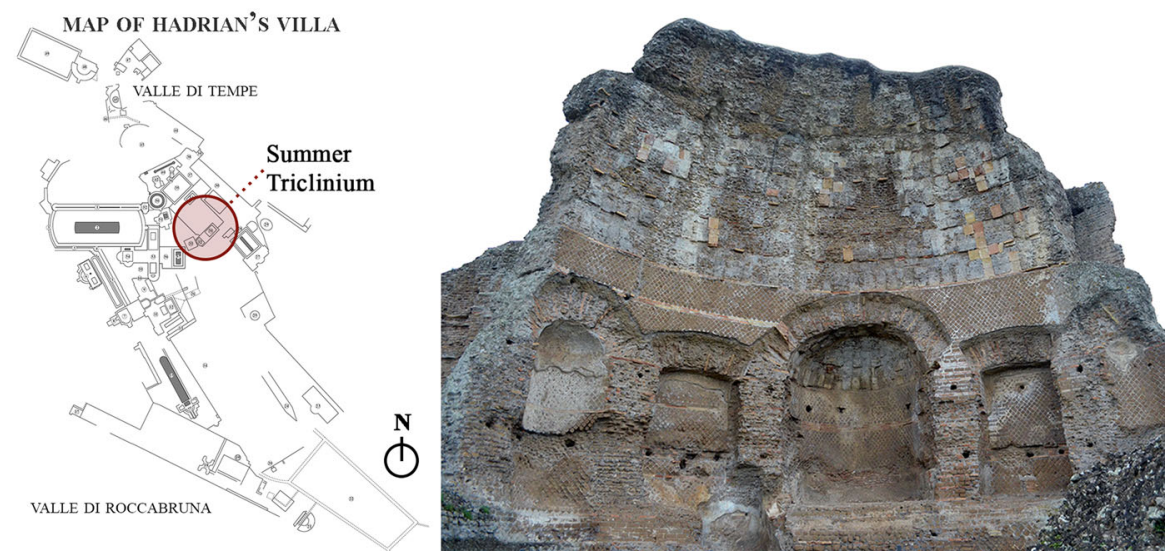

Fig. 3 Example of a semi-dome perceivable at the end of narrow paths/colonnades (Summer Triclinium)

It appears that the late chronological development of the various buildings (approximately built from North to South) corresponds to an increase in experimentation and the major monumental nature of the building. From this perspective, it is safe to say that some building features of the first phase seem to be prototypes for further phases. In particular, the Summer Triclinium of the Palazzo (Fig. 3) appears to be a small-scale and more conventional version of the Serapeum (Fig. 4), ${ }^{12}$ and the Small Bath's Octagonal Hall seems like a different-sized model for larger exemplars of cupolas in the Accademia and Piazza d'Oro (Fig. 5).

12 This is an interesting hypothesis by Cinque and Lazzeri (2010: 62-63). 

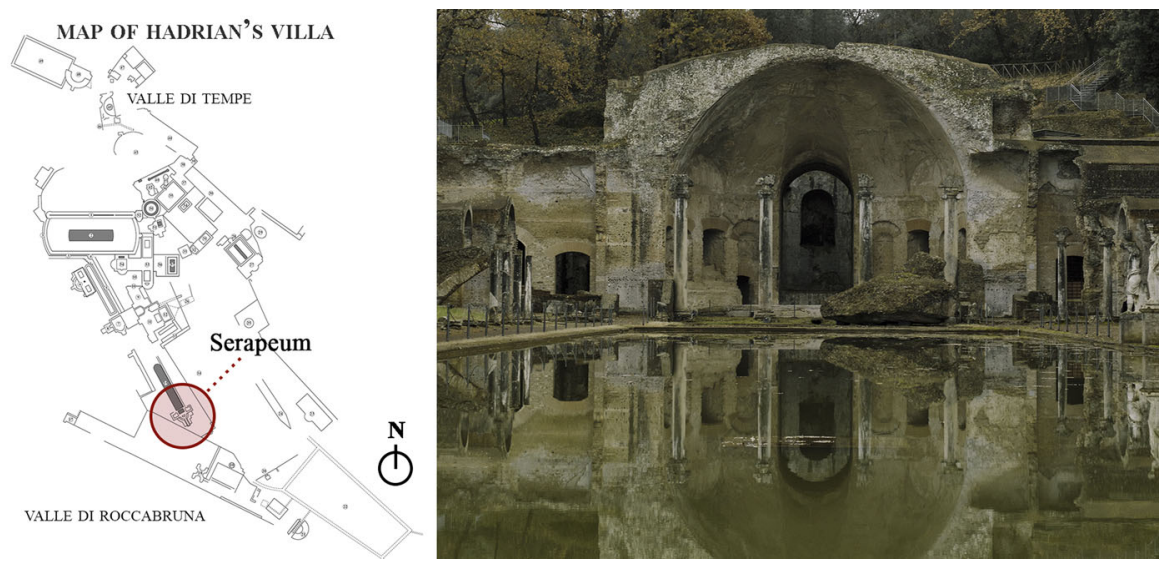

Fig. 4 Example of a semi-dome perceivable at the end of the colonnades (Serapeum and Inferi)

\section{The Hadrianic "Laboratory" for Conceiving New Domical Structures}

The Palatine Hill and the Domus Aurea in Rome present elements of interest for an exhaustive and complete reading of opus caementicium domes before Hadrian's time, whereas the Pantheon ${ }^{13}$ probably had a good status in 125 A.D. (i.e., at the end of the Villa's first phase). There is also a less evident but fundamental topic relating to the rapid evolution of the design features inside the villa itself during its hectic implementation (Adembri et al. 2016). From this point of view, the Maritime Theatre is emblematic because it is characterised by an original mixtilinear shape. Indeed, this feature is particularly evident in the very core of the structure - the impluvium — where the outer perimeter (a rectangular shape whose sides are interrupted in the middle by curved elements) becomes a mixtilinear irregular octagon in the core of the domus (Fig. 6). The entablature, which is characterised by a continuous frieze with a bas-relief representing chariot races on the one side and maritime thiasos on the other, became sought after by Renaissance antique collectors. However, it was the object of systematic despoiling conducted by the Neapolitan architect Pirro Ligorio, who worked for the cardinal Ippolito d'Este, one of the first surveyors of the Villa (Adembri 2013). In the second construction phase of Hadrian's mansion, these entablatures gained far more importance, not only from the perspective of decoration but also as structural elements supporting heavy cupolas. Examples of such structural tasks can be seen at the Eastoriented Piazza d'Oro triclinium (pointing towards the so-called Valle di Tempe) (Fig. 7). The circular domus built during the first construction phase of the Villa was then a first "embryonic" experiment by Hadrian's architects towards the development of the original geometric solution of the plan. In the second phase, further elements present in the first nucleus were mixed and developed into more sophisticated and daring structures in which the mixtilinear octagon-based plans gained more importance. In this sense, the experience of the Small Thermal Baths and Piazza d'Oro's Vestibule can be read as

\footnotetext{
13 This matter remains a source of debate because the date of the conclusion of the Pantheon is far from being certain. For more on this topic, see Jones (2015).
} 

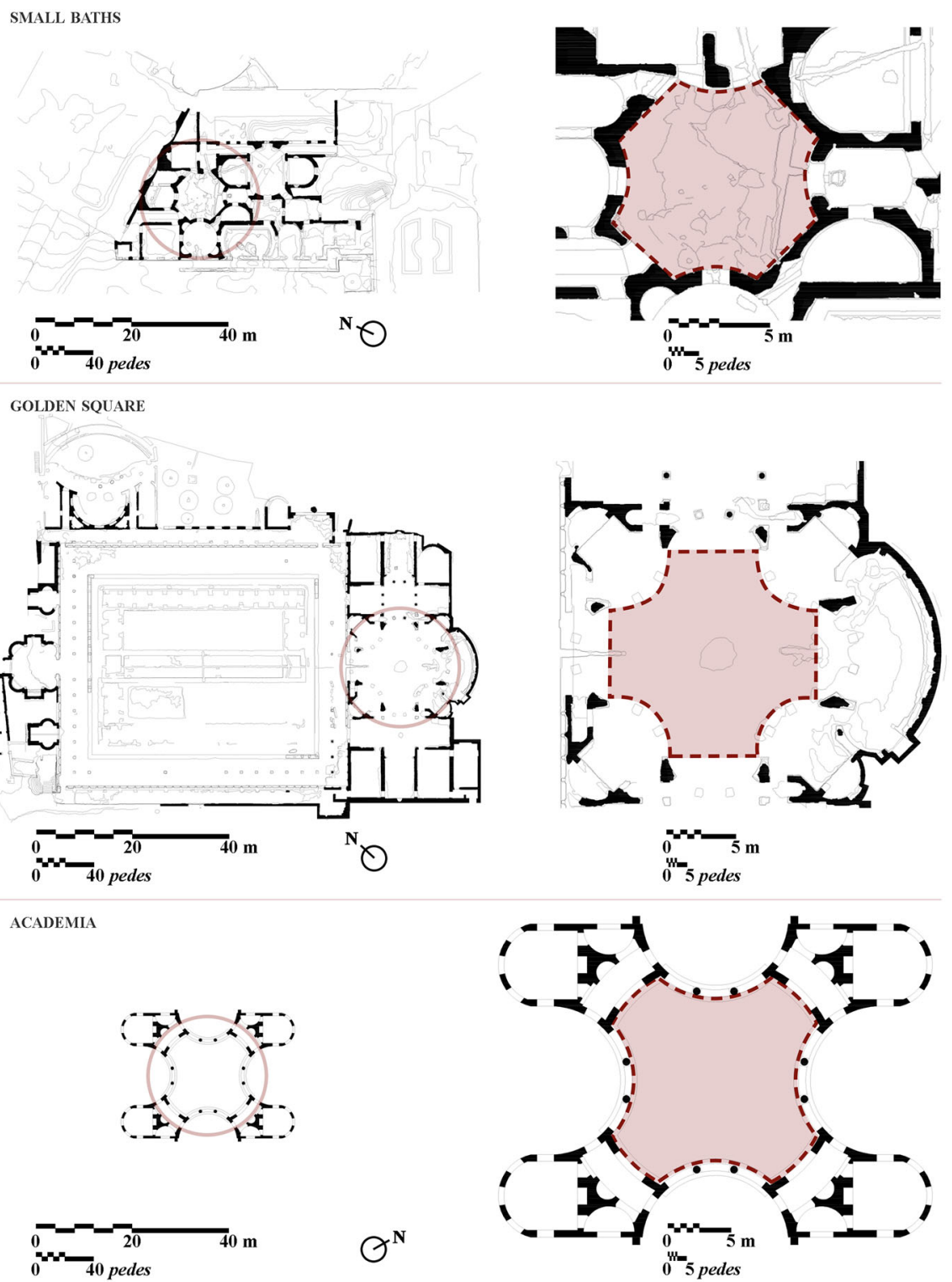

$\bigodot^{\mathbf{N}}$

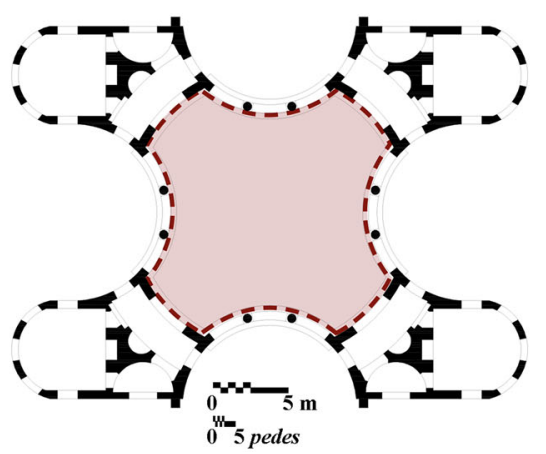

Fig. 5 Comparison between the vaulted structures of the most renowned complexes of Hadrian's Villa, which have plans based on mixtilinear octagons. On the left, comparison of the plans at the same scale; on the right, the corresponding details of the shape of the cupolas (at different scales). Top: Small Baths' Octagonal Hall built during the first construction phase (118 A.D./121 A.D.); middle: Piazza d'Oro built during the second phase (125 A.D./128 A.D.); bottom: the reverse-curve pavilion of the Accademia (built during the second phase) 


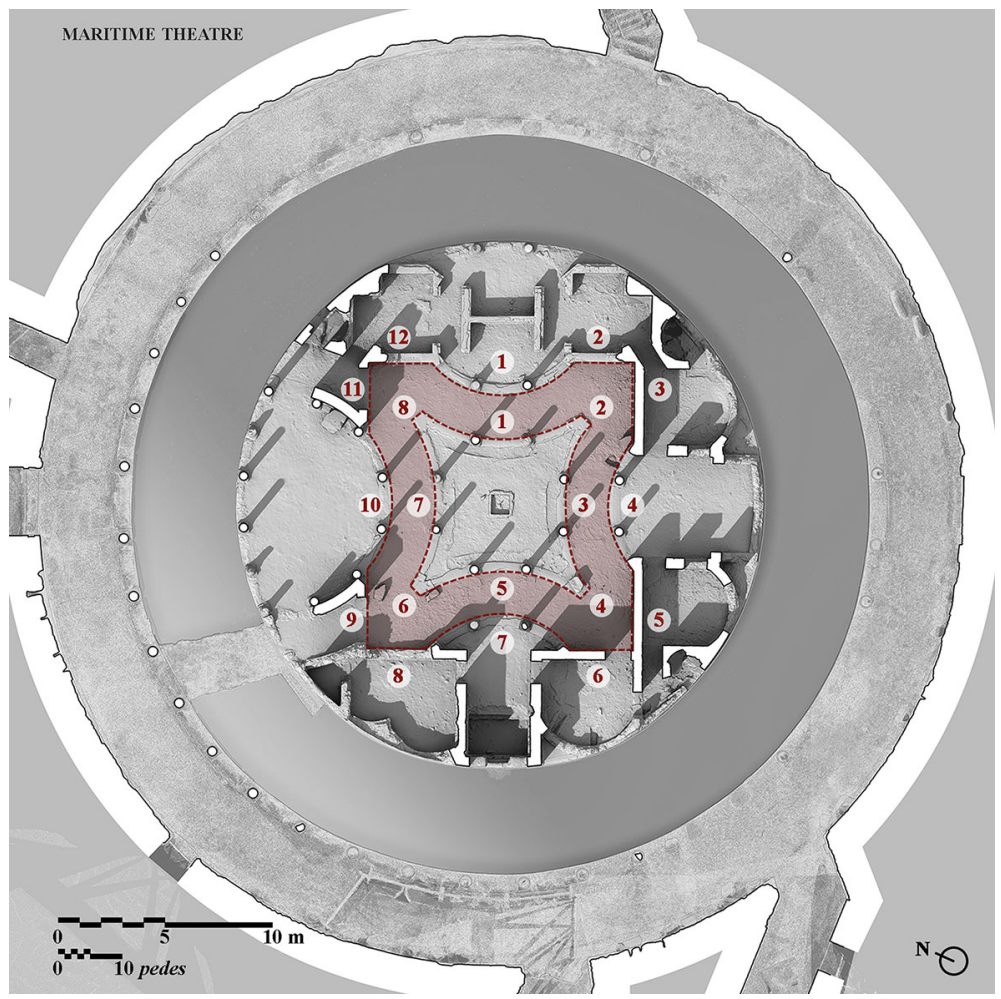

Fig. 6 The Maritime Theatre plan: rendering of the central portico. The outside 12-sided silhouette turns into an 8 -sided central nucleus

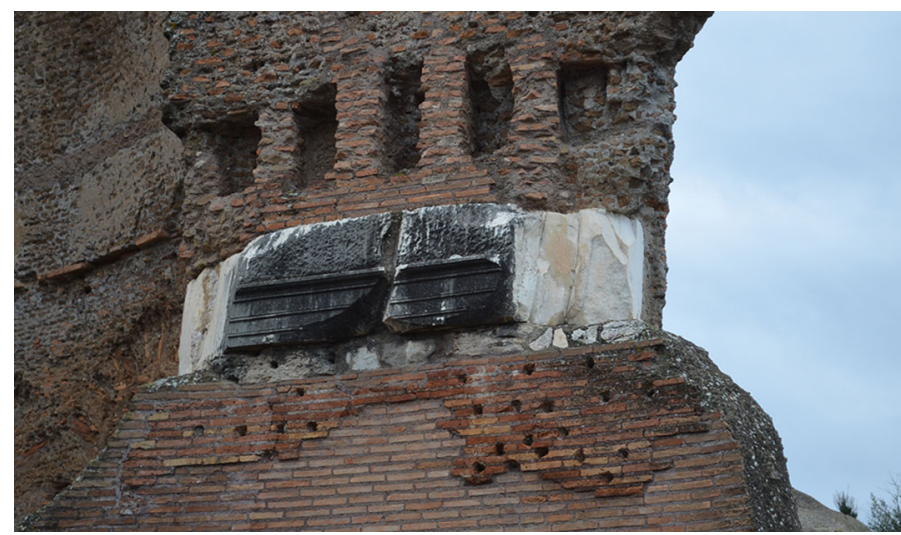

Fig. 7 Detail of the marble entablature embedded in the masonry at the Triclinium of Piazza d'Oro (Photo by F. Fantini) 

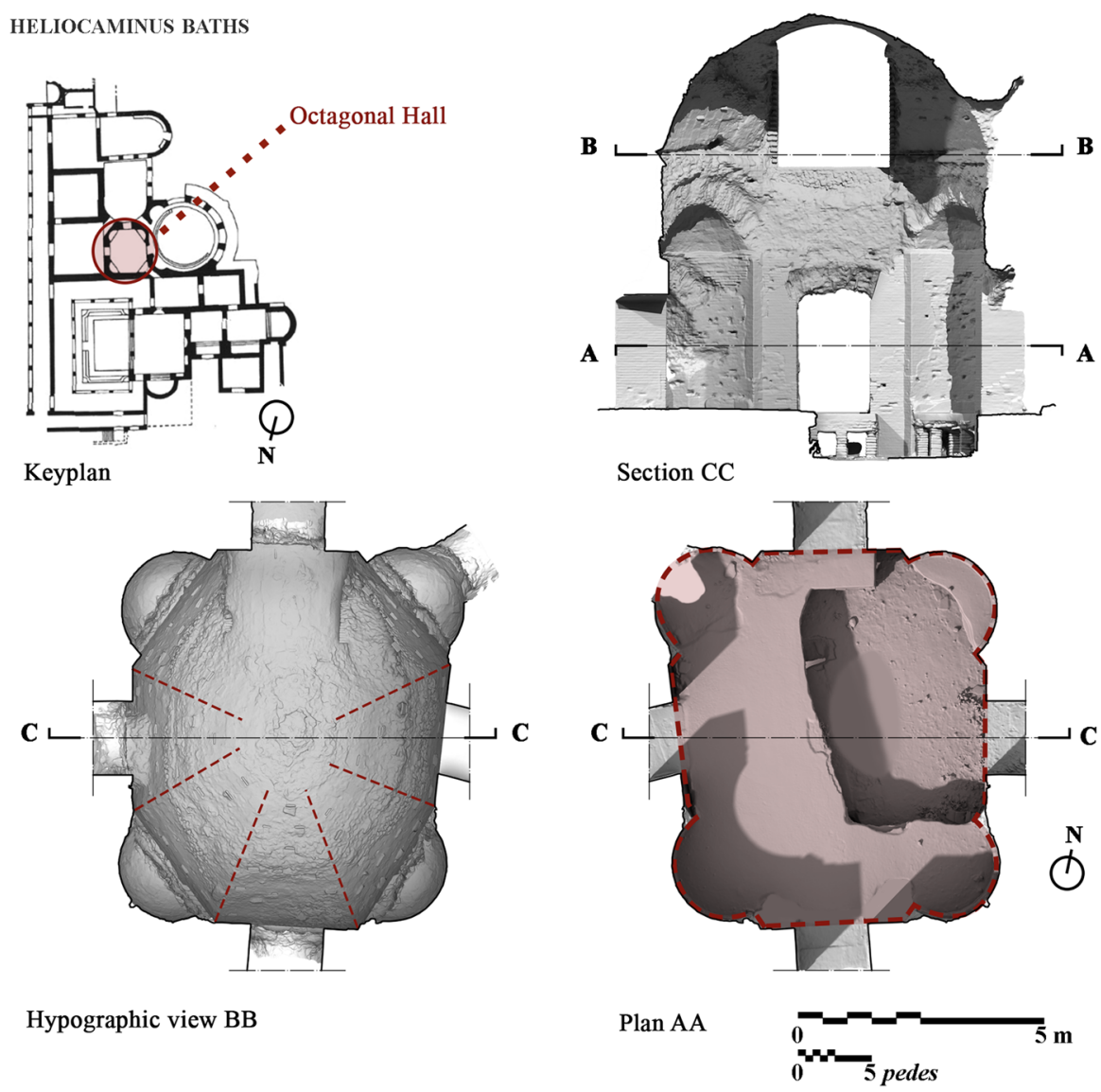

Hypographic view BB

Fig. 8 The distribution hall at the Heliocaminus Baths: the irregular octagon containing four niches introduces features that will become more complex in the second construction phase of the Villa

logical consequences of Hadrianic architects' effort to achieve a hybrid between mixtilinear central plans and the cloister vaults made in opus caementicium present at the Villa's Heliocaminus Baths (Fig. 8) and inside Domus Augustana at the Palatine Hill.

Another important issue relating to Roman domes concerns the very poor quantity of ancient literary sources on their design and construction. In fact, even if we had at our disposal an accurate and reliable representation of the domes' shapes via modern remote sensing technologies, it is evident that a proper analysis should be performed by observing 3D models as the product of a coherent and structured design method based on the general theoretical rules of the Vitruvian first book on Architecture and more "recent" or updated technical literature on specific problem solving. ${ }^{14}$

\footnotetext{
${ }^{14}$ Regarding the roles of different literary sources ranging from theoretical to technical, to better understand the design process of buildings for spectacles, see Bianchini and Fantini (2015: 26-36), particularly on the topic of the integration between Vitruvius and Heron of Alexandria. The first author supplies the reader with the six concepts/tools to be applied for every proper new design (ordinatio, dispositio, and distributio to achieve the qualities of eurythmia, symmetria, and decor). Then, for a limited
} 
On the topic of roman cupolas, Giangiacomo Martines wrote two seminal essays (Conti and Martines 2010; Martines 2014) drawing attention to the fact that the construction of thin domes in Roman concrete during the age of Nero was the consequence of a series of developments not only in the field of material technology but also, and above all, in design methodologies. To the best of our knowledge, the only treatise on vaults from antiquity is that by Heron of Alexandria. Unfortunately, it has been irretrievably lost. According to historians, the work would predate Hadrian's principate (i.e., the second half of the first century A.D.), but not substantially. This treatise is mentioned by Eutocius of Ascalon ${ }^{15}$ in his commentary on the work entitled "On the Sphere and Cylinder" by Archimedes, in which he explicitly refers to geometric shapes that are unusual compared to the formal collection of the Classical age, such as the parabola:

And one can draw the parabola using the compass invented by our master, (the mechanical engineer) Isidore of Miletus, having all been tested by him in the commentary that he wrote on Heron's treatise on domes (Martines 2014: 280).

At this stage, it seems certain that Nero's architects, Severus and Celer, ${ }^{16}$ who were in charge of the construction of the famous octagonal hall of the Domus Aurea, one of the few centralised vaults preserved between the construction of the Temple of Mercury's dome at Baiae (Fig. 9) and the Pantheon dome (Lancaster 2005: 42), possessed knowledge learned by reading the text of the Alexandrian mathematician, who, according to Martines (2014: 288), also supplied the reader with practical components relating to groin layouts, formworks and carpentry in general, in addition to geometrical and statistical concepts applied to solid geometries and 3D figures (Fig. 10).

As examined in previous studies (Bianchini and Fantini 2015), even in the cultural climate of the Hadrian age and, particularly, at the Villa, it seems that architects applied Heron of Alexandria's methods of calculation. One vivid example is the marble model of a building for spectacles in which the formulas contained in Stereometrica 40-43 (Heiberg 1914: 45-49) and De Mensuris 24 to determine the theatre's capacity are largely applied, and Heron uses an intermediate semi-circle to calculate the cavea's capacity.

\footnotetext{
Footnote 14 continued

set of typologies, he describes the geometric constructions to be used for dimensioning and shaping buildings' parts. Heron's manuals (Heiberg 1914) are centred on mathematic formulas to be applied to solve very specific problems (in particular, Stereometrica and De mensuris) grouped into categories of shapes but are not directly framed into a general architectural design method. Rather, they are just a concise list of recursive problems. For this reason, integrating different literary sources is fundamental because they are intrinsically incomplete due to their authors' scopes.

15 It must be noted that this is the only record of the treatise on vaults (tà kamarikà) by Heron; not all philologists agree on this specific line of the text.

16 Tacitus (Annals, 15-42-1) calls them magistri et machinatores. Martines (2014: 294) clarifies the meaning of the term machina as scaffoldings: "in the construction of vaults, the wooden centering for the casting of concrete was also considered to be a machina".
} 
Fig. 9 Interior of the Temple of Mercury at Baiae, Naples (late Republic or early Imperial age). Photo by F. Fantini
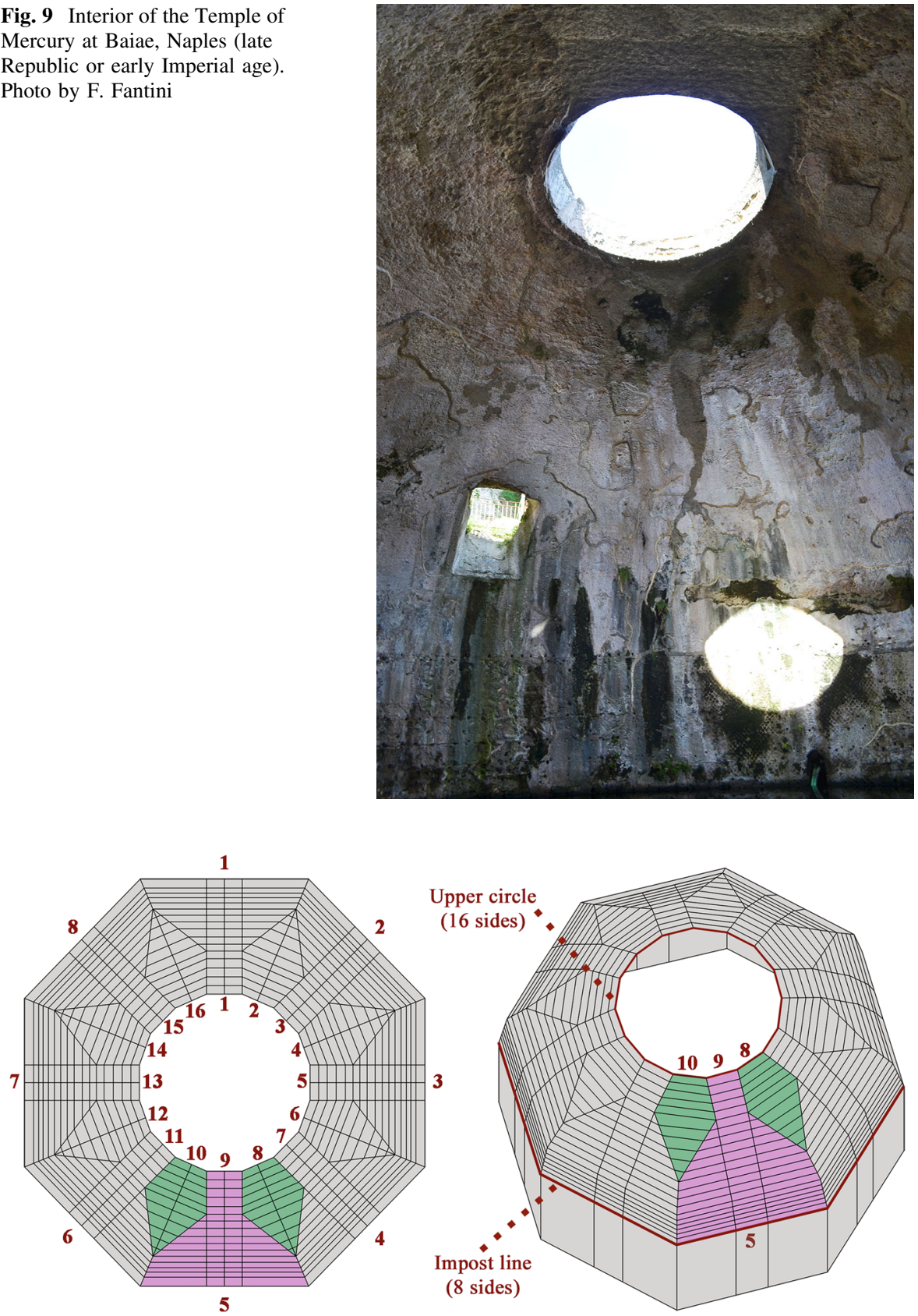

Fig. 10 Graphic scheme for centring works of the octagonal hall of the Domus Aurea (A.D. 64-68) (original drawing by Lancaster 2005: 43) 
Fig. 11 Graphical interpretation of Heron's formula for volumetric calculation from Stereometrica. (1) Original drawing taken from Heron's Stereometrica, V, 29 (Heiberg 1914: 107, Fig. 58). Arabic numerals corresponding to the ancient Greek alphabetic numerals present in the drawing: $\overline{i \delta}=14, \quad \bar{\zeta}=14, \quad \bar{\zeta}=$

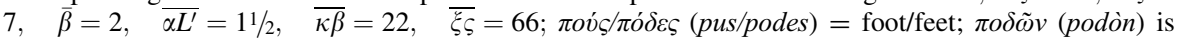
the plural genitive of the term. (2) The interpretation of Heron's calculation formula and verification of the hypothesised 3D model. Calculation procedure as explained by Heron in the problem. PERIMETER: $[1] \mathbf{p}=(\mathbf{b}+\mathbf{h})(\mathbf{1}+\mathbf{1} / \mathbf{2 1}) ; b=14 ; h=7 ; 14+7=21 ; 21+\left(21 \times 21^{-1}\right)=21+1=22$. Measures shown in colour are given in the text; black notes with arrows are added by the authors. The hypothesis consists of considering the average circle as the calculated semiperimeter in red and not the intrados of the arch, as stated by Heiberg (1914: 109). (3) VOLUME: V=d $\times \mathbf{t} \times \mathbf{p} ; d=2 ; t=1 \frac{1}{2} ; 2 \times 1 \frac{1}{2}=3$; $3 \times 22=66$. Heron's formula for the semiperimeter is valid if the base doubles the vertical line, and the latter is equal to the radius of the circle. In this specific case, [1] becomes $\mathrm{b}=2 \mathrm{r} ; \mathrm{h}=\mathrm{r} ; \mathrm{p}=3 \mathrm{r} \times 22$ / $21=\mathrm{r} \times 22 / 7$. The value $22 / 7$ is the approximation commonly used for $\pi$. (4) Red line: Heron's approximation for the semiperimeter $(\mathrm{p}=\mathrm{r} \times 22 / 7)$. Black line: semiperimeter using the mathematical constant $\pi(\mathrm{p}=\mathrm{r} \times \pi)$. Scheme and interpretation by S. Bertacchi

Heron's $\Sigma \tau \varepsilon \rho \varepsilon о \mu \varepsilon \tau \rho \iota \kappa \dot{~ a l s o ~ a d d r e s s e s ~ t h e ~ c a l c u l a t i o n ~ o f ~ v o l u m e s ~ b y ~ i l l u s t r a t i n g ~}$ several examples of practical rules for finding approximate volumetric values. ${ }^{17}$ In particular, starting from problem n. 28 on page 104 (raw 9), together with the nine following exercises in the text (up to page 122, raw 2), the examples concern vaulted structures or domes and the calculus of the mass necessary for the assessment of construction materials.

Those vaulted structures in the "manual" are small in size, and $\pi o v ́ / \pi o ́ \delta \varepsilon \varsigma$ (pous/ podes $=$ foot/feet) is the unit of measurement used for all the exercises. According to Martines (2014: 289), the structures are made of bricks and permeated by Byzantine tradition in terms of their shapes, probably because of the spurious nature of the work. Despite the information, and although the figures show Greek annotations and reference numbers, interpreting the actual correspondence is, unfortunately, quite difficult. The proportions given in the text seem not to match the drawings, which are simple 2D outlines of arches/vaults/domes and most likely present elevation views. Moreover, some notes refer to lengths, whereas others refer to volumes, and even the comments by Heiberg cannot clarify the use of some approximate formulas for the empirical calculation.

This is the case of the arch, for which the calculated circle's perimeter is approximated without the use of the constant pi $(\pi=3.14)$ through a formula that sums up the span and the sagitta of the arc and adds a fraction equal to $\frac{1}{21}$ of the total value to obtain the inner circumference. In the German commentary, the author notes its general inaccuracy except for this case due to the correspondence of the height of $7 \pi \delta \delta \varepsilon \varsigma$ for the semicircle with a radius equal to 7 . He also relates the value to the inner circumference, but Heron's calculus for the volume would be incorrect if tested with a solution considering an irrational number. Our alternative interpretation considers Heron's formula applied to the average semicircle representing the arc with an offset of 1 on each side for a depth of $2 \pi o \delta \varepsilon \varsigma$ and then multiplies this value by the product of the thickness and the depth of the

\footnotetext{
17 The original ancient Greek text with parallel German translation and commentary on figures is taken from the 5th volume of the edition Heronis Alexandrini, Opera quae supersunt omnia by Heiberg (1914, reprint 1976). See also Martines (2014: 289) and note n. 44 in the text.
} 
(1)

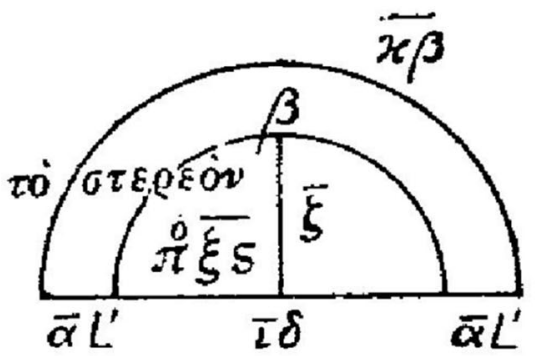

(2)

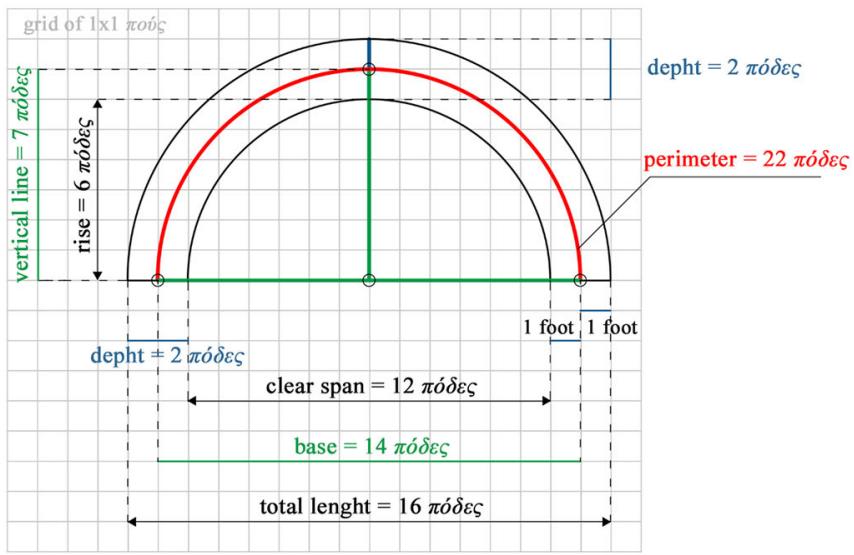

(3)
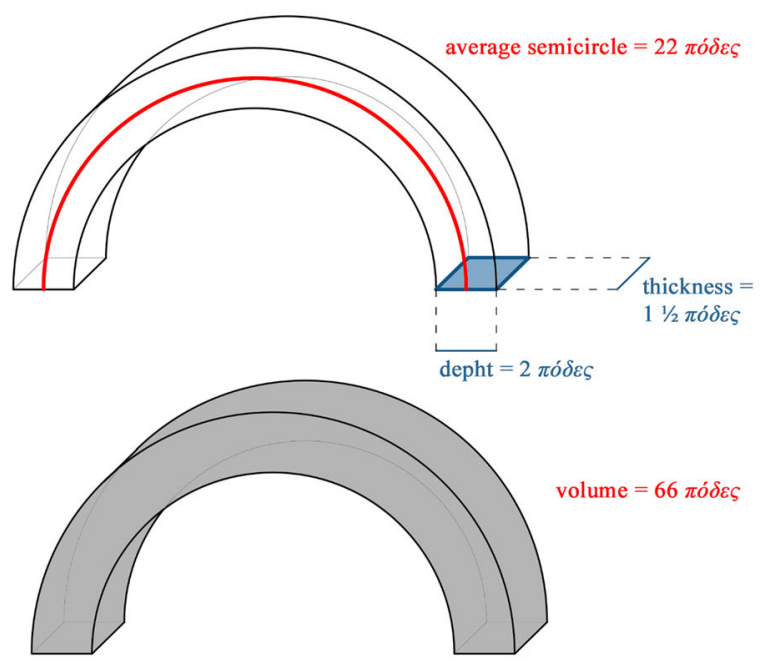

(4)

error $=+0.0089$ feet 
keystone to calculate the approximate volume. ${ }^{18}$ For more details on this example, refer to problem n. 29, which is explained in Fig. 11.

Considering a vault, which base is equal to $14 \pi \delta \delta \varepsilon \varsigma$, the vertical line $=7$ $\pi \delta ́ \delta \varepsilon \varsigma$, and the keystone has a depth of $2 \pi \delta \delta \varepsilon \varsigma$, the thickness of $1 \frac{1}{2}$, in order to find the perimeter and the volume: add together the base and the vertical $(\mathrm{b}+\mathrm{h}=14+7=21)$; then add $\frac{1}{21}$ of the value $(b+h)\left(1+\frac{1}{21}\right)=$ $21\left(1+\frac{1}{21}\right)=21+1=22$ [1]. This is the perimeter. Then multiply the keystone's depth by the vault's thickness and the result by the perimeter to find the total volume. Respectively $2 \times 1 \frac{1}{2}=3$, then $3 \times 22=66 \pi \delta \delta \varepsilon \varsigma$. That is the volume. ${ }^{19}$

Heron's solution is correct only if $14 \pi \delta$ ó $\varepsilon \varsigma$ represents the diameter of an average arc and not the clear span of the arch; consequently, $\mathrm{R}$ (outer radius) $=8 \pi \delta \delta \varepsilon \varsigma$ and $\mathrm{r}$ (inner radius) $=6 \pi \delta \delta \varepsilon \varsigma$. The volume is correct and equals $66 \pi \delta \delta \varepsilon \varsigma \varsigma^{20}$

Moreover, Heiberg annotates that this is the only case in which the function is true because the height is equal to 7 . Actually, this formula is always valid if the base is double the height, with the latter equal to the radius of the average arc; that is, $\mathrm{b}=2 \mathrm{~h}=2 \mathrm{r}$. Thus, $\mathrm{b}+\mathrm{h}=3 \mathrm{r}$. The semiperimeter in [1] becomes $3 r\left(1+\frac{1}{21}\right)=3 r\left(\frac{22}{21}\right)=r \frac{22}{7}$. With $\frac{22}{7}$ being the fraction commonly used to approximate $\pi$, the semiperimeter calculated by Heron (i.e., $s=r \frac{22}{7}$ ) is almost equal to the modern $\mathrm{s}=\frac{p}{2}=\mathrm{r} \pi$.

Therefore, within the scope of this study focused on Hadrianic domes, there is an additional objective: understanding whether the remarkable shapes of the Villa's cupolas can be considered as the outcome of a development process started 70 years earlier with Severus and Celer or as the original achievements of Hadrian's architects. Obviously, in the absence of written sources, the only possibility is to start with a set of hypotheses based on geometric/formal clues directly extracted from 3D meshes of octagonal-based cupolas (regular or mixtilinear). If these shapes are common features emerging from the archive of digital models, some new assumptions concerning the design method of complex roofing schemes between Nero and Hadrian can be made. ${ }^{21}$

\footnotetext{
18 The interpretation given is the result of an ongoing analysis that will be completed with the translation and redrawing of Heron's problems on vaulted structures aiming to deepen our knowledge on the topic of vaulted constructions.

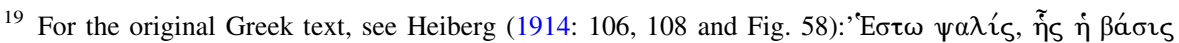

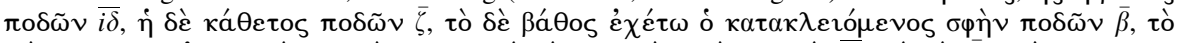

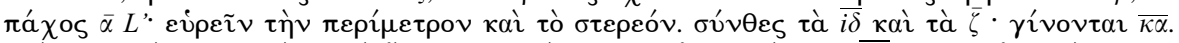

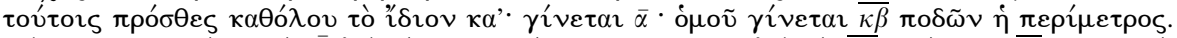

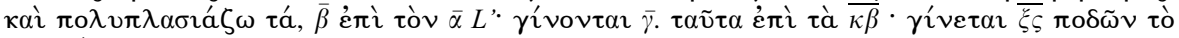

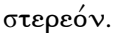

${ }^{20}$ In contrast, if the span is $14 \pi \delta \delta \varepsilon \varsigma, \mathrm{R}=9$, and $\mathrm{r}=7$; thus, $\mathrm{V}=75.39 \pi \dot{\delta} \delta \varepsilon \varsigma$. Verification of the calculation: Volume of a hollow semicylinder: $\mathrm{V}=\frac{\pi\left(R^{2}-r^{2}\right) \mathrm{h}}{2}=\frac{\pi\left(8^{2}-6^{2}\right) 1.5}{2}=\pi 21=65.9734 \pi \delta \delta \varepsilon \varsigma \approx 66$ $\pi o ́ \delta \varepsilon \varsigma$, in agreement with Heron's solution.

21 Among the buildings that incorporated complex cupolas on octagonal drums with niches, it should be noted that the so-called Baths of Nero in Pisa include a small octagonal sudatio (hot room) that presents a dome with nine rectangular holes between each groin and the addition of a central oculus on the top (Campus 2015). For a complete and still unsurpassed survey of octagonal cupolas in the Roman and Late Antiquity ages, see De Angelis D’Ossat (1936).
} 
These are remarkable issues that can be studied only through formal and constructive analyses to resolve long-standing debates among historians and archaeologists who, in many cases, expressed doubt regarding whether geometric patterns underlie the most daring experiments at the Villa. For example, in the case of the Octagonal Hall at the Small Baths, "It is impossible to describe the domes at Hadrian's Villa from a geometrical point of view, and in particular the so-called Apodyterium of the Tiburtine Small Baths" (Viscogliosi 2006: 332).

\section{Geometric Analysis of the Octagonal Hall}

The Small Baths (Fig. 12), the Great Baths and the Canopus-Serapeum complex are aligned with an axis that runs half a kilometre from the Poecile up to the niche of the great Serapeum triclinium. The thermal complex was built against the pre-existing back wall of a courtyard between the Edificio con Tre Esedre and the Garden Stadium of the Winter Palace nucleus (MacDonald and Boyle 1980: 5).

The octagonal room of the complex has a function similar to that of the irregular octagon, with niches for Heliocaminus Baths (Fig. 8), whose primary purpose mainly relates to the spatial distribution within the bathhouse complex. The room shows significant portions of the original roofing in a good state of conservation, but to the bare eye, it is very difficult to grasp its geometric genesis. In contrast, the authentic shape of the dome at the Domus Aurea is difficult to distinguish because it seems to be some sort of octagon blending into an upper circle. A similar appearance is also present at the so-called Baths of Nero (Puma 2013), where the octagonal prism of the drum gradually turns into a cloister vault, and eventually, the

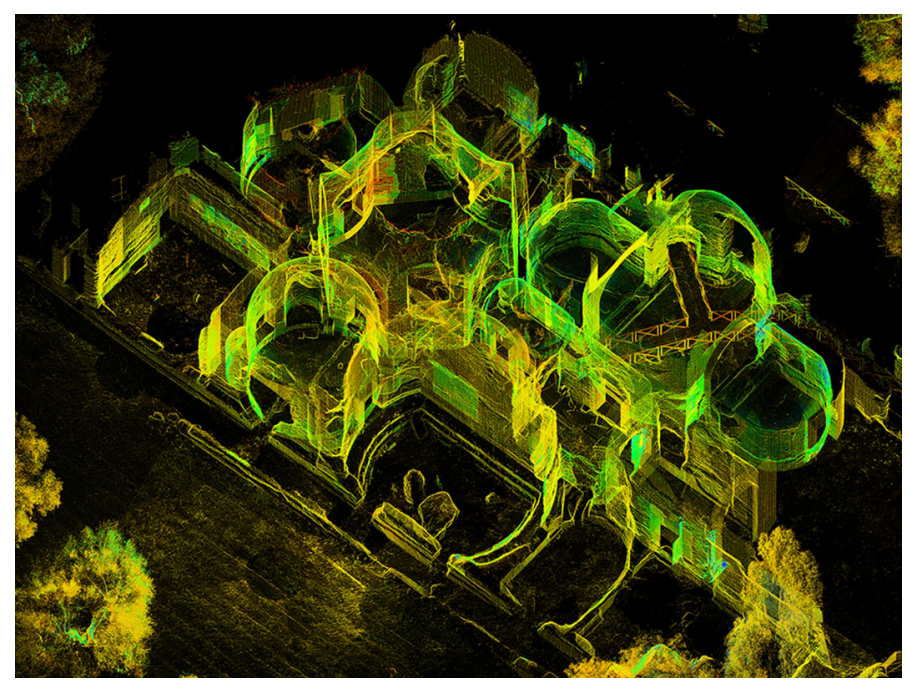

Fig. 12 View of the point cloud model of the Small Baths complex. Digital survey by the authors in 2015 (Adembri et al. 2015: 24) 

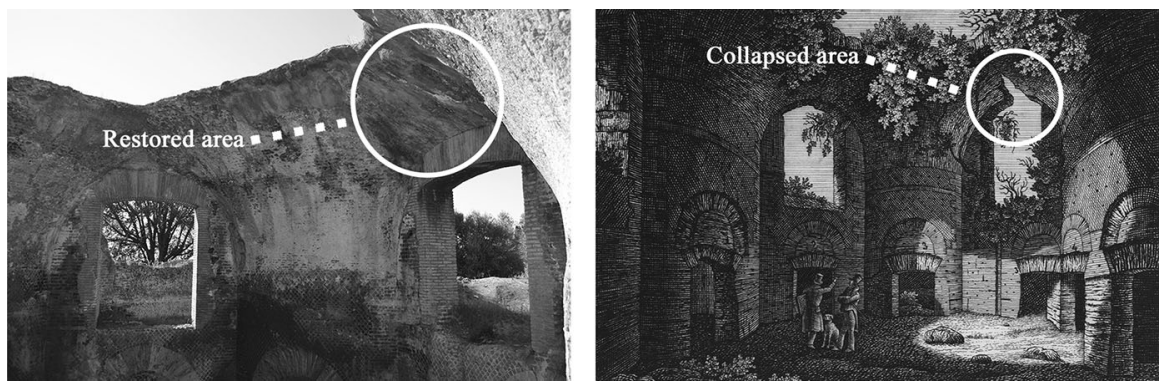

Fig. 13 On the left, photo documenting the current state of conservation of the Small Baths' roofing with restorations. On the right, highlighted area for comparison with the state of conservation during Agostino Penna's survey (1836). The presence of a vast crack is evident in his drawing

eight groins fade into an undifferentiated shape on the top of the roofing, ending in an oculus.

In addition to the intrinsic complexity of the vault, other issues must be considered. Indeed, man-made alterations (i.e., not deliberate restorations) and deterioration caused by the passage of time have significantly altered the original shape (Fig. 13). However, a structural feature of the Roman vaulted architectures should also be noted because it could lead to a misinterpretation of the original shape. The presence of uneven ancient thick mortar (up to $10 \mathrm{~cm}$ ) laid upon masonry and concrete highlights a relevant issue impacting the ability to distinguish the supporting structure from the finishing structure. ${ }^{22}$

Due to the intrinsic low accuracy of the construction method, which resulted in deformations and deviations between the orientations of walls, two types of sections have been used:

1. The first set corresponds to a small number of horizontal and vertical planes relating to the ancient design method (in particular, ichnographia and orthographia). These sections can, in turn, be subdivided into two categories: true and detailed representations of the shape through a spline and approximations of the section through best-fitting geometries, particularly circles (Figs. 14, 15).

2. A second set of sections consists of contour lines that provide hints relating to the understanding of the general flow of the curvature of the complex and deteriorated shape of the vault's remains (Fig. 14, right).

The first statement concerns vertical sections passing through curved sides (Fig. 14, left) because the consistency of the dome's remains allows best-fitting circles to be reliably drawn. Their radii (equal to $5.22 \mathrm{~m}$, on average), once converted into roman pedes (0.2956 m; Duncan-Jones 1980), are approximately equal to $17+\frac{1}{2}+\frac{1}{6}$ pedes and are tangent to the supposed height of the original floor.

\footnotetext{
${ }^{22}$ For an exhaustive description of the surveying campaign (i.e., the equipment, software and quantitative aspects of the mesh model) and the procedures adopted to analyse the 3D model of the Small Baths, see Cipriani et al. (2016: 302-306).
} 


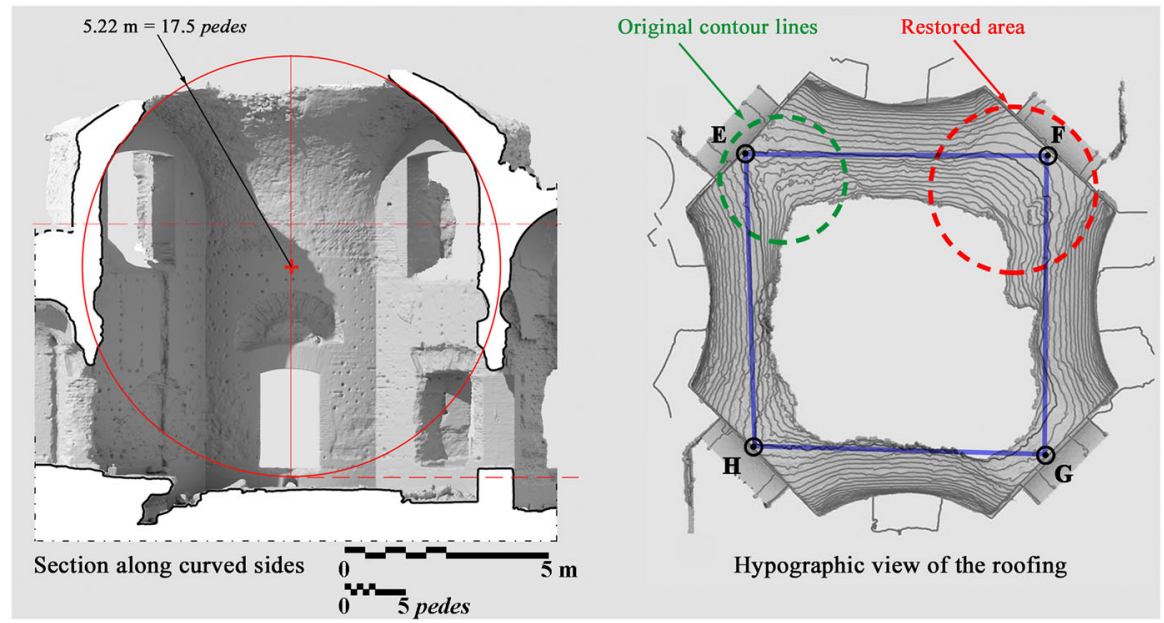

Fig. 14 On the left, vertical section with the best-fitting circle passing through the middle of the curved sides (Cipriani et al. 2016: 302) and on the right, hypographic view of the digital model with contour lines highlighting the different shapes of the original and restored areas of the cupola

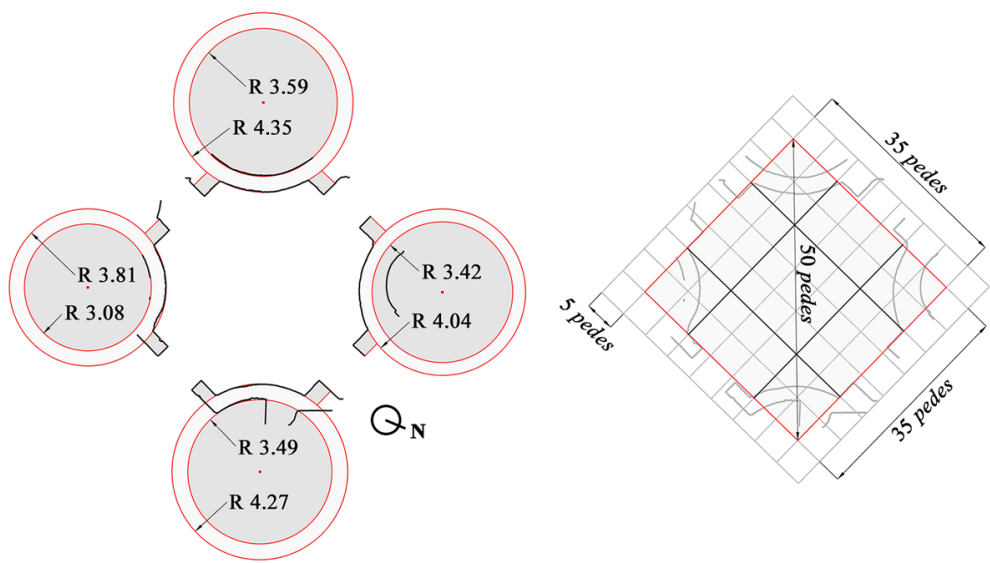

Fig. 15 Curved elements and linear elements shaping the hall: the firsts are obtained by slicing the model at the height of the dome impost line; then, through a reverse modelling application, best-fitting circles passing through the curved sides were identified (left). Right The grid of 5 pedes used for the general dimensioning of the hall is based on Frederick Rakob's study (1967) that interpreted the plan using approximated measures of the square (sides and diagonal)

Among the research focusing on this mixtilinear hall, Rakob (1967) and Jacobson (1986) provide interesting suggestions that are confirmed by measurements extracted from the highly detailed model. According to Rakob, the basic module present in the hall plan is equal to 5 pedes and was used by the ancient architect for the construction of the octagonal shape (Fig. 15), starting from a square with edges of 35 pedes and a diagonal of 49.49 (probably approximated to 50 pedes during the physical tracing in the construction site). All things considered (i.e., the state of 

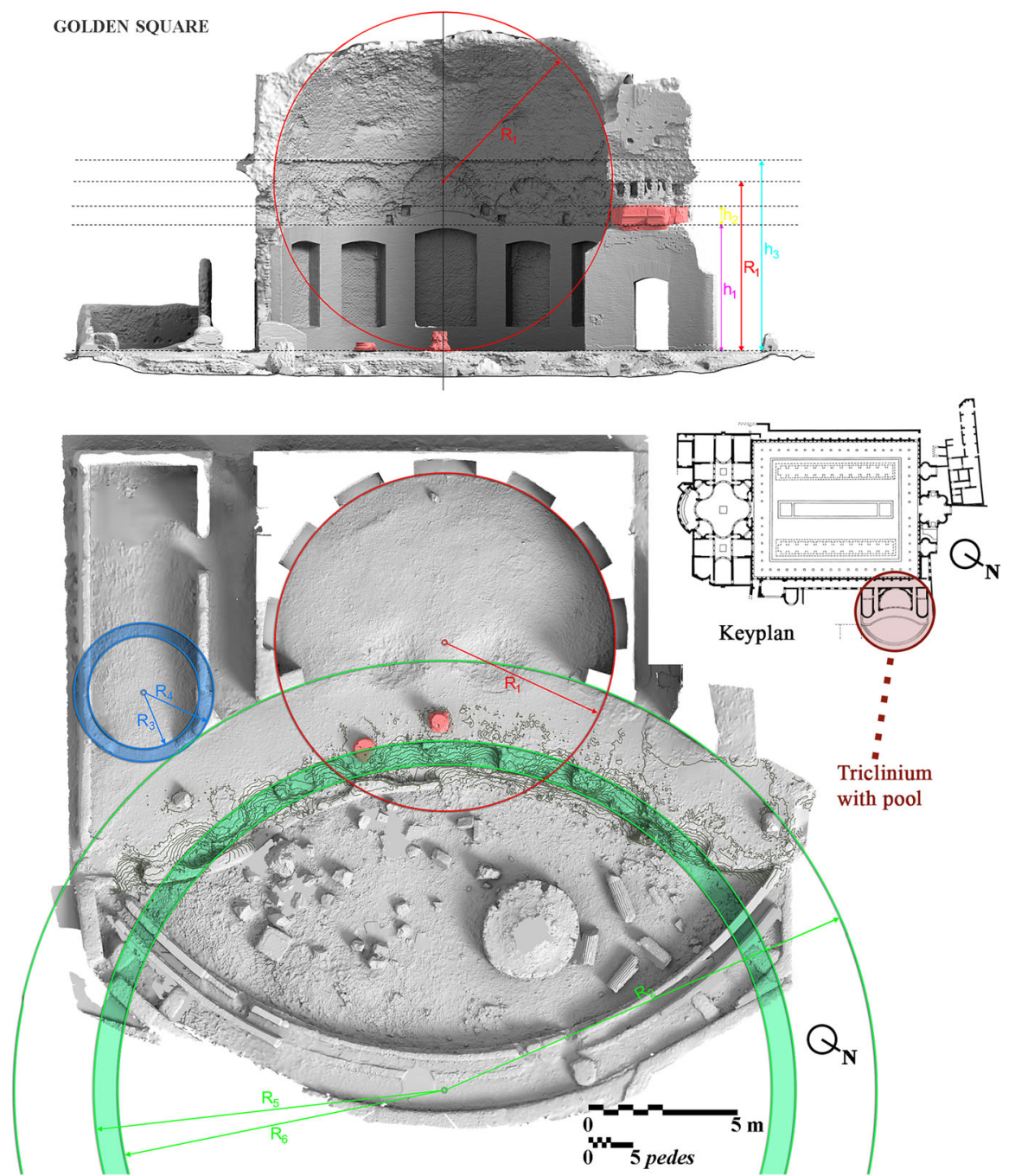

Fig. 16 The triclinium at the Piazza d'Oro: keyplan of Piazza D'Oro, elevation (Adembri et al. 2015: 28) and plan with the main bend radii in evidence (3D model renderings by F. Fantini), and main measures: $\mathrm{R}_{1}=5.729 \mathrm{~m}=19+\frac{3}{8}$ pedes, $\mathrm{R}_{2}=14.543 \mathrm{~m}=49$ pedes, $\mathrm{R}_{3}=11.845 \mathrm{~m}=6+\frac{1}{4}$ pedes, $\mathrm{R}_{4}=2.353 \mathrm{~m}=8$ pedes, $\mathrm{R}_{5}=11.824 \mathrm{~m}=40$ pedes, $\mathrm{R}_{6}=11.017 \mathrm{~m}=37$ pedes, $\mathrm{h}_{1}=4.224 \mathrm{~m}=14+\frac{1}{4}$ pedes, $\mathrm{h}_{2}=0.646 \mathrm{~m}=2+\frac{1}{5}$ pedes, and $\mathrm{h}_{1}=6.434 \mathrm{~m}=21+\frac{3}{4}$ pedes.

conservation and the low accuracy of the construction), 35 pedes could correspond to the radius of the best-fitting circle passing through the curved sides $\left(17+\frac{1}{2}+\frac{1}{6}\right.$ pedes $)$ and diverging by just $\frac{1}{6}$ pedes $(4.926 \mathrm{~cm})$. It is safe to say that this circle can be inscribed into the square of the ichnographia $(35 \times 35$ pedes $)$, consistent with a ratio present in many other Hadrianic buildings (e.g., the triclinium of the Piazza d'Oro, Fig. 16). 
For the curved sides, Jacobson (1986: 80) proposes an array of 9 circles inscribed inside a grid formed by squares of 32 pedes. Rakob (1967) suggests a simpler and intelligent geometric construction based on the linear edge of an octagon equal to 15 pedes, but the average based on the best-fitting circles is equal to $13+\frac{1}{2}$ pedes. ${ }^{23}$ For the design of the curved sides, a different solution seems more fitting because that proposed previously diverges from the best-fitting circles to a greater degree than that proposed by the authors (Cipriani et al. 2013) ${ }^{24}$ (Fig. 17).

The $\mathrm{CC}$ section seems to highlight the presence of a linear slope matching the lunette in point $\mathrm{E}$, similar to a longitudinal ridge rib tangent to the best-fitting circle in $\mathrm{M}$ (Fig. 18).

Therefore, the architects may have used a similar geometric pattern for both the plan and elevation. Due to the state of conservation of the masonry, achieving an exact result is very difficult. However, based on the set of contour lines extracted from the mesh (Fig. 14, right), it is possible to determine that the drum mixtilinear shape is converted into a series of ruled surfaces once it becomes a dome, with the exception of the restored parts (Fig. 14, right).

The hypothesis of the design process that led to the final shape of the dome is summarised in Fig. 19:

1. First, the intersection curve between the cylindrical surface extruded from the plan and a cylinder with a diameter of 35 pedes is identified. The double curvature curve $c$ is then intersected with the impost plane at points $\mathrm{A}$ and $\mathrm{B}$.

2. Two vertical planes $\alpha$ and $\beta$ passing through $A$ and $B$, respectively, and the centre $\mathrm{V}$ of the plan define two curves, $t$ and $u$. A first surface forming the collapsed dome is than defined. This patch is defined by three curves: $t, u$ and part of curve $c$ between points A and B. Curves $t$ and $u$ are obtained by intersecting the cylinder with a horizontal axis with two vertical planes $\alpha$ and $\beta$.

3. In accordance with the general flow of the dome provided by the reliable parts of the contour lines (Fig. 14, right), at the height of the upper parts of the lunettes, the mixtilinear octagon turns into the square EFGH, idealised in Fig. 19 (3). This square belongs to a horizontal plane that once intersected with curves $t$ and $u$ determines two points $\mathrm{C}$ and $\mathrm{D}$ aligned to segment $\mathrm{EH}$. A ruled surface can now connect curve $v$ of the lunette and the part of $t$ between points A and D.

4. The square EFGH intersects 8 curves ( 2 per side) and, in the case of the segment EH, 3 (segments HC, CD and DE). Thus, the square can potentially be split into 12 segments. Similar to the hypothesis of the octagonal hall at the Domus Aurea proposed by Lancaster (2005: 42-44, see also Fig. 10), in which the octagonal cloister vault is progressively converted into a hexadecagon, Hadrian's architects may have split the square in 12 to facilitate its connection to a regular polygon (in this case a dodecagon) by means of 12 ruled surfaces.

\footnotetext{
23 The four best-fitting circles (Fig. 15) present slightly different radii ranging from 3.81 to $4.35 \mathrm{~m}$. Three of the circles are quite similar, whereas the one near the circular hall of the calidarium is far larger than the others.

24 The average errors between different authors' circumferences and best-fitting circles are as follows: Jacobson $1986=0.590 \mathrm{~m}$, Rakob $1967=0.316 \mathrm{~m}$, and Cipriani et al. $2013=0.221 \mathrm{~m}$.
} 

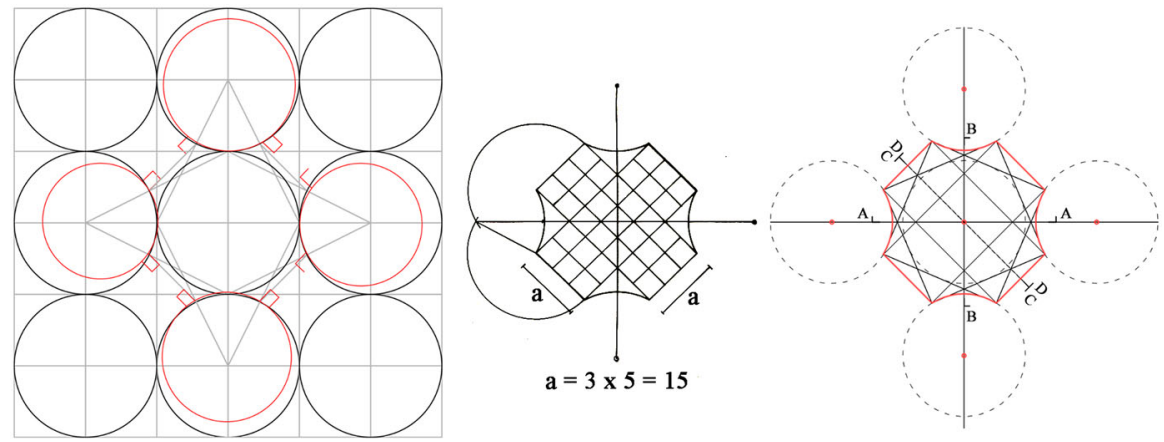

Fig. 17 Comparison of different geometric constructions of the hall plan. Left (Jacobson 1986), middle (Rakob 1967), and right (Cipriani et al. 2013)

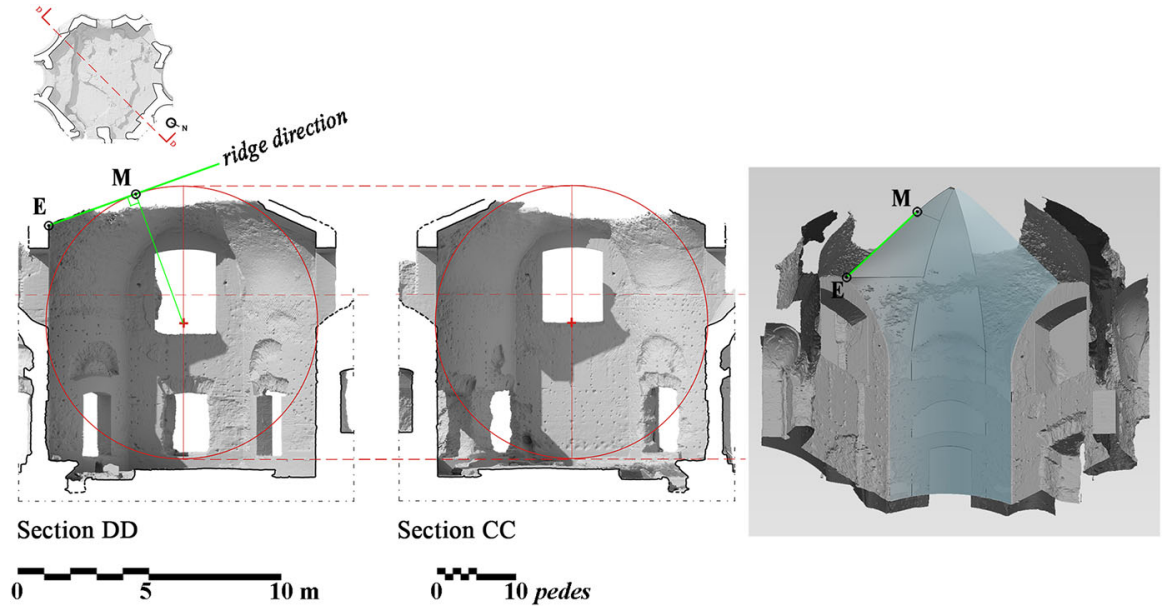

Fig. 18 Sections along the lunettes (DD and CC) with a possible hypothesis of the ridge direction highlighted (Cipriani et al. 2016: 313-314). Right Axonometric view of the mesh and non-uniform rational basis spline (NURBS) models obtained by means of reverse modelling procedures overlapped to a sector with the hypothetical completion of the dome and an approximated spherical cap

The height of the horizontal plane containing the dodecagon could be the result of the tangency relation between the vertical best-fitting circle in Fig. 18 and the oblique ridge of the lunette, namely, point M (Figs. 18, 19).

\section{Conclusions}

The exact terms of the geometrical problem are still far from being deeply understood because of the vault's state of conservation and the low accuracy of its construction. This is unfortunate because the geometry underlying its design was very advanced and intelligent. The solution adopted to give a partial, though not 

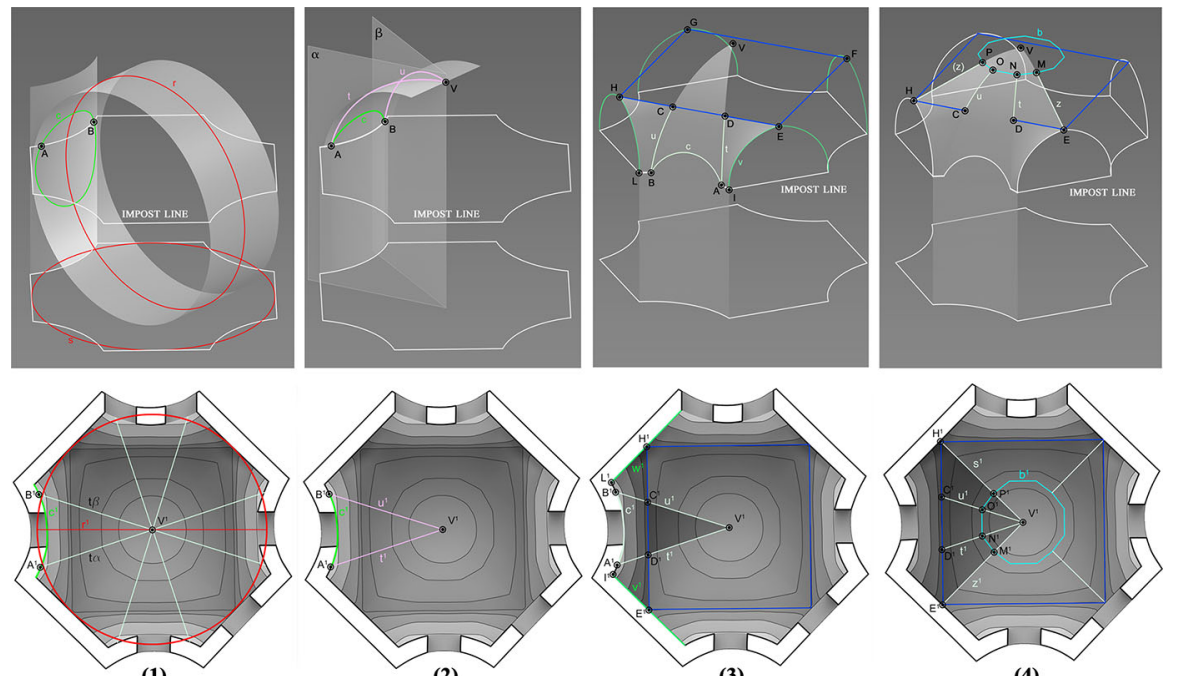

(1)

(2)

(3)

(4)

Fig. 19 Hypothesised octagonal cupola design sequences

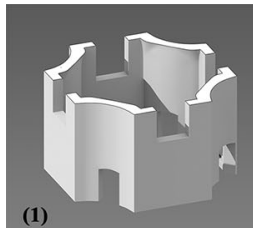

(1)

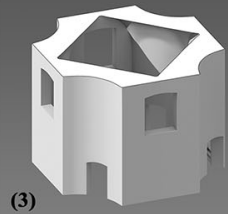

(3)

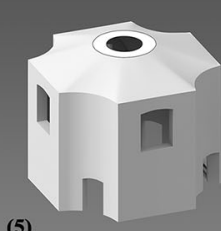

(5)

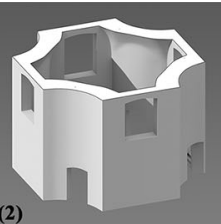

(2)

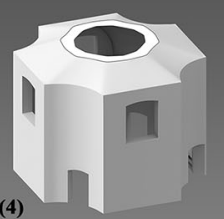

(4)

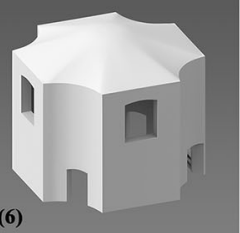

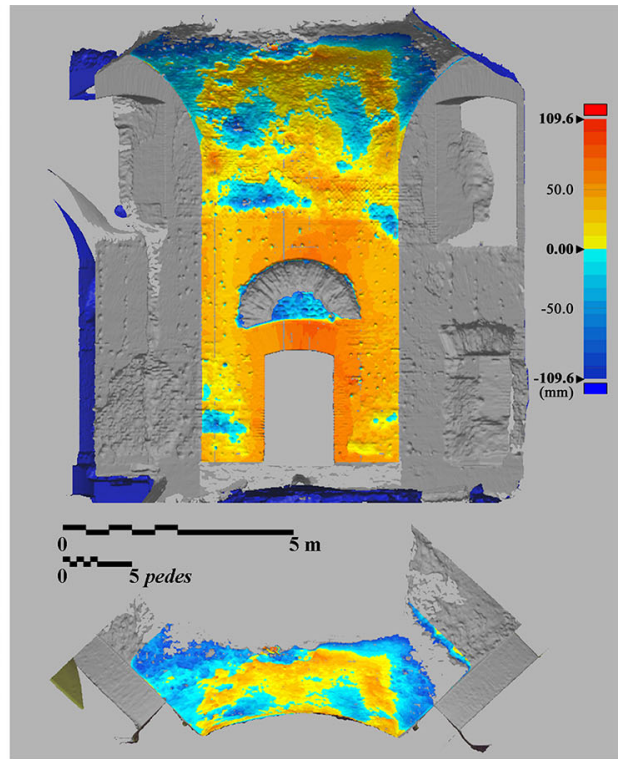

Fig. 20 Final idealised model: summary of the main geometric features/constructive steps and comparison of the model with the highly detailed mesh. The maximum positive and negative deviations are within $10.96 \mathrm{~cm}$

complete, solution is based on contour lines obtained from a highly detailed mesh. From these contour lines, it is possible to observe that the geometric continuity of the vault is no more than a skilful fake because the blending from a convex wall to a 


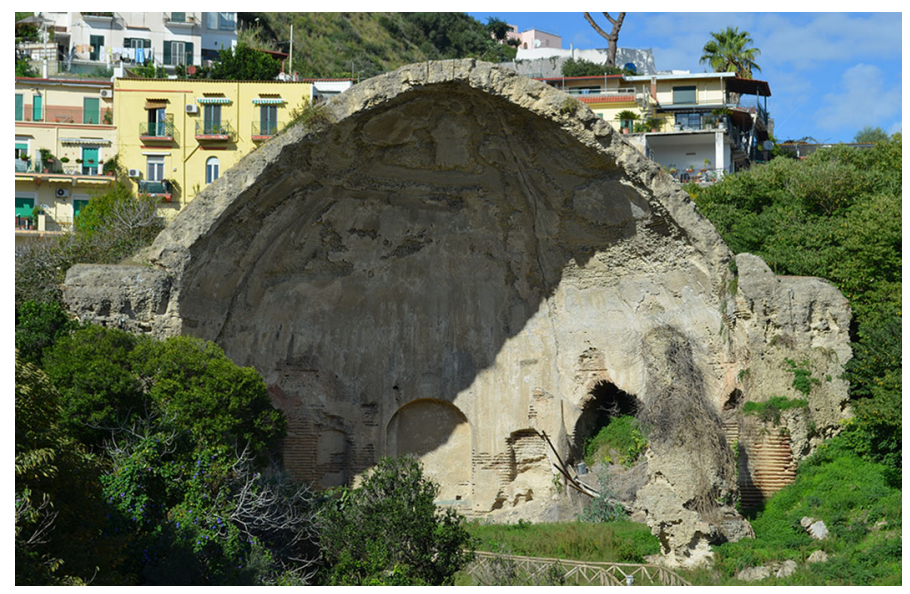

Fig. 21 Temple of Diana (Baiae). Photo by S. Bertacchi

concave spherical cap on the top of the dome is achieved through the use of simple ruled surfaces that approximately converge on a top dodecagon.

In the frame of the vast architectural renovation process conducted by Hadrian, the octagonal hall of the Small Baths in Tivoli plays a fundamental role because it can be considered as a halfway point between the very first example provided by the Domus Aurea's Octagonal Hall and other later examples, such as the so-called Temple of Minerva Medica in Rome and the mosque of Little Hagia Sophia in Constantinople (formerly the Church of the Saints Sergius and Bacchus).

Our hypothesis is that the ancient architect decided to customise previous achievements by Severus and Celer in design and construction. Indeed, the dome is the product of shape blending, similar to Nero's Domus Aurea, in which a regular octagon turns into a regular polygon of 16 sides.

The final idealised 3D model of the vault was obtained using both NURBS and Subdivision Surface modelling techniques; a sector of the idealised model was then compared with the relatively preserved and regular part of the masonry to visually determine the magnitude of the deviation (Fig. 20).

Further studies will focus on the Golden Square's Vestibule and the so-called Serapeum in Tivoli-prototypes of umbrella-shaped vaults-and on the late Hadrianic vaults in Baiae, near Naples (Fig. 21). The aim is to understand analogous, variable, and invariable elements among the vaults using state-of-the-art surveying devices and reverse modelling applications.

\section{References}

Adembri, Benedetta. 2013. Villa Adriana, Villa d'Este e il reimpiego: i fregi figurati curvilinei del teatro Marittimo e di Piazza d'Oro. In: Ippolito II d'Este, cardinale, principe, mecenate, eds. Marina Cogotti and Francesco Paolo Fiore, 351-366. Roma: De Luca Editori d'Arte. 
Adembri, Benedetta, Cinque, Giuseppina Enrica and Elisabetta Lazzeri. 2010. Cupole, volte e calotte: la magnificenza dell'impero. In: Disegnare il tempo e l'armonia. Il disegno di architettura osservatorio nell'universo, eds. Emma Mandelli and Gaia Lavoratti, vol. 2, 680-687. Firenze: Alinea

Adembri, B., Cipriani, L., Fantini, F. and S. Bertacchi. 2015. Reverse designing: an integrated method for interpreting ancient architecture. SCIRES-it 5 (2): 15-32.

Adembri, Benedetta, Cipriani, Luca, Filippo and Fantini. 2016. Illustrare, pianificare e costruire nel mondo antico: casi di studio da Villa Adriana. In: I Tracciati di cantiere: disegni esecutivi per la trasmissione e diffusione delle conoscenze tecniche, eds. Carlo Inglese and Antonio Pizzo, 90-107. Roma: Gangemi.

Adembri, Benedetta, Di Tondo, Sergio, Fantini, Filippo and Fabio Ristori. 2014. Nuove prospettive di ricerca su Piazza d'Oro e gli ambienti mistilinei a pianta centrale: confronti tipologici e ipotesi ricostruttive. In: Adriano e la Grecia. Studi e ricerche, eds. Elena Calandra and Benedetta Adembri, 81-90. Milano: Electa.

Adembri, Benedetta, Juan-Vidal, Francisco and Isabel Martínez-Espejo Zaragoza. 2012. Hunting friezes of the Piazza d'Oro at Hadrian's Villa. New hypothesis for a virtual reconstruction inside an integrated research strategy. In: Proceedings of the $16^{\text {th }}$ International Conference on Cultural Heritage and New Technologies (CHNT 16), Vienna, 14-16 November 2011, 140-153. http://www. chnt.at/proceedings-chnt-16/. Accessed 1 Nov. 2016.

Bertocci, Stefano. 2015. Documentation of Hadrian's Villa at Tivoli: digital survey for conservation and evaluation of archaeological areas. In: Libro Comunicaciones/Paper Book, III Congreso Internacional sobre Documentación, Conservación y Reutilización del Patrimonio Arquitectónico y Paisajístico, Valencia, 22, 23 y 24 de Octubre de 2015, 2130-2137. Valencia: Editorial Universitat Politècnica de València.

Bianchini, C. and F. Fantini. 2015. Dimensioning of Ancient Buildings for Spectacles Through Stereometrica and De mensuris by Heron of Alexandria. Nexus Network Journal 17 (1): 23-54.

Cairoli, G. 1975. Ricerche sull'architettura di Villa Adriana. Roma: De Luca Editore.

Calandra, E. 2013. Adriano princeps e committente. Forma Urbis 18 (8): 4-11.

Caliari, P.F. 2012. Tractatus logico sintattico: la forma trasparente di Villa Adriana. Roma: Edizioni Quasar.

Campus, A. 2015. Le "Terme di Nerone" a Pisa: restituzione volumetrica e ricostruzione tridimensionale. Il Mulino-riviste web 2-3: 120-130.

Cinque, Giuseppina Enrica. 2013. Le componenti progettuali nell'architettura della villa Adriana: il nucleo centrale. In: Roma, Tibur, Baetica, Investigaciones Adrianeas, eds. Rafael Hidalgo Prieto and María del Pilar León Alonso, 95-150. Sevilla: Secretariado de Publicaciones, Universidad de Sevilla.

Cinque, G.E. and E. Lazzeri. 2010. Analisi geometriche e progettuali in alcuni complessi di Villa Adriana. Romula 1: 55-84.

Cipriani, L., F. Fantini and S. Bertacchi. 2013. Criteri di indagine degli spazi voltati nell'ambito dell'architettura storica e in archeologia. SCIRES-it 3 (2): 101-134.

Cipriani, Luca, Fantini, Filippo and Silvia Bertacchi. 2016. 3D Digital Models for Scientific Purpose: Between Archaeological Heritage and Reverse Modelling. In: Handbook of Research on Emerging Technologies for Architectural and Archaeological Heritage, ed. Alfonso Ippolito, ch. 10, 291-321. Hershey, PA: IGI Global.

Conti, Cinzia and Giangiacomo Martines. 2010. Hero of Alexandria, Severus and Celer: Treatises and Vaulting at the Nero's Time. In: Mechanics and Architecture between episteme and téchne, ed. Anna Sinopoli, 79-96. Roma: Edizioni di Storia e Letteratura.

De Angelis D’Ossat, Guglielmo. 1936. Sugli edifici ottagonali a cupola nell'antichità e nel Medio Evo. In: Atti del I Congresso Nazionale di Storia dell'Architettura (29-31 Ottobre 1936-XV), 13-24. Firenze: Sansoni.

Di Tondo, S. 2007. La Forma di Villa Adriana nel Territorio tiburtino. Ph.D. thesis, Università di Firenze.

Dio, Cassius. 1925. Roman History (3rd AD), Volume VIII, Books 61-70. Ed. and trans. Earnest Cary. Cambridge: Loeb Classical Library/Harvard University Press.

Duncan-Jones, R.P. 1980. Length-Units in Roman Town Planning: The Pes Monetalis and the Pes Drusianus. Britannia 11: 127-133.

Giuffrida, E. 2007. La ricorsività dell'actus nel progetto planimetrico di "Villa Adriana". Studio delle geometrie sottese. Ph.D. thesis, Sapienza Università di Roma. 
Gizzi, Stefano. 2002. Tivoli, la villa Adriana. In: Italia Antiqua. Envois degli architetti francesi (18111950). Italia e area mediterranea, eds. Olivier Bonfait and Annie Jacques, ch. 58, 82-90. Parigi: École nationale supérieure des beaux-arts.

Hansen, E., Nielsen, J., Asserbo, J. and T. Jespersen. 2011. Due cupole a Villa Adriana. Calcoli statici. Analecta Romana Instituti Danici 35/36: 83-100.

Heiberg, J.L. 1914. Heronis Alexandrini, Opera quae supersunt omnia. Stuttgart: Teubner (rpt. 1976).

Hoffmann, Adolf. 2009. Villa Adriana a Tivoli. In: Storia dell'architettura italiana. Architettura romana. I grandi monumenti di Roma, eds. Henner Von Hesberg and Paul Zanker, 290-299.

Jacobson, D.M. 1986. Hadrianic Architecture and Geometry. American Journal of Archaeology (AJA) 90 (1), 69-85.

Jones, Mark Wilson. 2015. Building on adversity: the Pantheon and problems with its construction. In: The Pantheon: From Antiquity to the Present, eds. Tod A. Marder and Mark Wilson Jones, 193-230. Cambridge: Cambridge University Press.

Lancaster, L.C. 2005. Concrete vaulted construction in imperial Rome. Innovations in context. Cambridge: Cambridge University Press.

MacDonald, W.L. and B.M. Boyle. 1980. The Small Baths at Hadrian's Villa. Journal of the Society of Architectural Historians 39: 5-27.

MacDonald, W.L. and J.A. Pinto. 1997. Villa Adriana. La costruzione e il mito da Adriano a Louis I. Kahn. Milano: Electa.

Mari, Z. and S. Sgalambro. 2007. The Antinoeion of Hadrian's Villa: Interpretation and Architectural Reconstruction. American Journal of Archaeology 111 (1): 83-104.

Martines, G. 2014. Isidore's Compass. A Scholium by Eutocius on Heron's Treatise on Vaulting. Nuncius 29: 279-311.

Moneti, A. 1992. Nuovi sostegni all'ipotesi di una grande sala cupolata alla Piazza d'Oro di Villa Adriana. Analecta Romana Instituti Danici 20: 67-92.

Penna, A. 1836. Viaggio pittorico della Villa Adriana composto dei musaici, pitture, statue ed altri oggetti rinvenuti nelle varie escavazioni condotto da Agostino Penna con una breve descrizione di ciascun monumento. Roma: della tipografia di Pietro Aureli.

Portoghesi, P. 1994. Francesco Borromini. Milano: Mondadori Electa.

Pucci, Mirco and Alessandro Blanco. 2011. Ad thermas: a system between private and public life in the ancient town. In: Proceedings of the $15^{\text {th }}$ International Congress "Cultural Heritage and New Technologies" (CHNT 2010, Wien, November 2010), 502-512. Wien: Museen der Stadt Wien Stadtarchäologie.

Puma, Paola. 2013. Le Terme di Nerone a Pisa. I rilievi per una nuova piattaforma di comunicazione e divulgazione. In: Actas del Congreso La Experiencia del Reuso, Propuestas Internacionales para la Documentación, Conservación y Reutilización del Patrimonio Arquitectónico (...), 265-271. Madrid: UPM.

Rakob, F.L. 1967. Die Piazza d'Oro in der Villa Hadriana bei Tivoli. Ph.D. thesis, University of Munchen.

Richardson, M., Stevens, M. H. Burns. 2000. John Soane architetto 1753-1837. Milano: Skira.

Salza Prina Ricotti, E. 2001. Villa Adriana. Il sogno di un imperatore. Roma: "L'Erma" di Bretschneider. Verdiani, Giorgio, Pucci Mirco and Alessandro Blanco. 2010. A ground test for enhancing the approach to the digital survey and reconstruction for archaeologists and architects. In: Proceedings of the $14^{\text {th }}$ International Congress "Cultural Heritage and New Technologies” (CHNT 2009, Wien, November 2009), 259-69. Wien: Museen der Stadt Wien - Stadtarchäologie.

Viscogliosi, Alessandro. 2006. Traiano e gli imperatori adottivi. In: L'architettura del mondo antico, eds. Corrado Bozzoni, Vittorio Franchetti Pardo, Giorgio Ortolani and Alessandro Viscogliosi, ch. 4, 298-338. Bari: Laterza.

Ward-Perkins, J.B. 1974. Architettura romana. Milano: Electa.

Ytterberg, M.R. 2013. The hidden Order of Hadrian's Villa, and the Order of Modern Architecture. Nexus Network Journal 15 (1), 127-154.

Luca Cipriani Associate Professor of Architectural Representation at the School of Engineering and Architecture of Bologna. He received a PhD in Civil Engineering and attended the VIII cycle of Research Doctorate in Engineering, Building and Territorial at the Faculty of Engineering, University of Bologna, in 1996. Investigation lines: study of the process of development and modification of the city, procedures 
and techniques of digital survey and 3D modelling of monuments and heritage. The research activity is documented by publications in peer reviewed journals and conference proceedings: Disegnare idee immagini, Parametro, Paesaggio urbano, VSMM, ISPRS, EGA Revista de expresión gráfica arquitectónica, International Conference of Education, INTED International Technology, Urban Data Management Symposium, Forum UNESCO, SPIE, SIGRADI. He has written several books among them: "The design of the portico of San Luca in Bologna" and "Examples of architectural design. The teaching of drawing in the Faculty of Engineering of Bologna".

Filippo Fantini Architect with a PhD in the Science of Surveying and Representation of Architecture and Environment at the Department of Architecture, University of Florence. Starting from 2004 he collaborates regularly with the Department of Architecture of the University of Florence participating in numerous surveying campaigns aimed at the documentation of sites from the particular historic and artistic interest such as: Villa Adriana (Tivoli), the Villa of Tiberius at Sperlonga (Latina), the walls of Massa Marittima (Grosseto), the Han Yang Ling Museum in Xian (Shaanxi, China) and the palace of Herod the Great at Masada (Israel). From 2009 to 2011 had the scholarship "Santiago Grisolia" at the Instituto de Restauración del Patrimonio (IRP) of the Polytechnic University of Valencia. Since September 2013 he is research professor at the Alma Mater Studiorum Università di Bologna, Campus of Ravenna. Main topics of research activity: Classical Archaeology, Ancient Greek and Roman Theatre, 3D Modelling, 3D Laser scanning, Digital Photogrammetry, Reverse Modeling.

Silvia Bertacchi Graduated with first-class honours at the University of Florence in 2009. She is an architect with a European $\mathrm{PhD}$ in the Science of Surveying and Representation of Architecture and Environment at the Department of Architecture, University of Florence. For the academic year 2015/2016 she was an adjunct professor of Drawing for the Bachelor Degree in Construction Engineering at the University of Bologna, of Descriptive Geometry for the Bachelor Degree in Industrial Design at the University of Florence and of Architectural Drawing at the Master Degree in Civil Engineering/ Architecture at the University of Pavia. At present she is research fellow at the Interdepartmental Centre for Industrial ICT Research of the University of Bologna. Her research is mainly focused on descriptive geometry, design, architecture and computer graphics and their application on architecture. 